\title{
The Response of Pilobolus to Light.
}

\author{
BY
}

ROSALIE PARR.

With four Figures in the Text.

Contents.

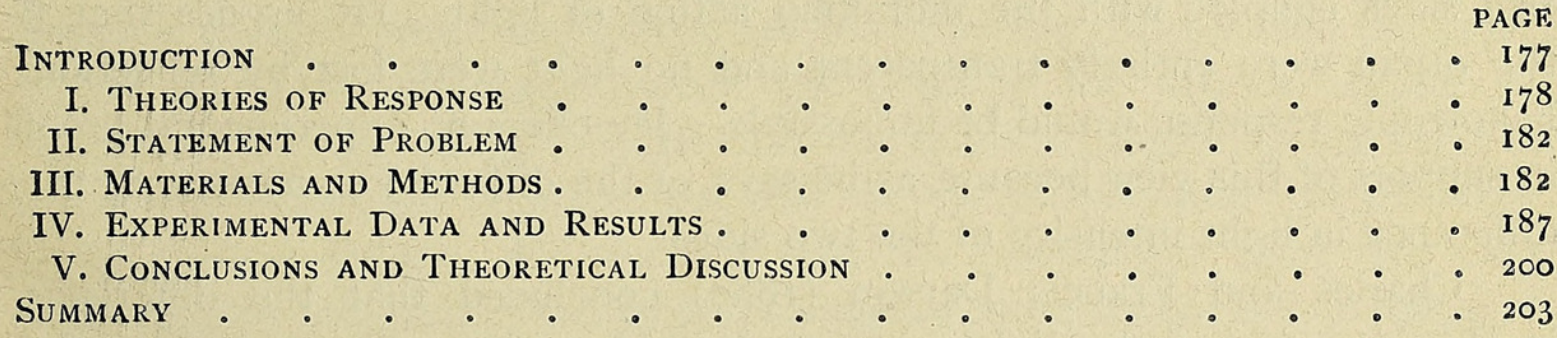

\section{INTRODUCTION.}

\ $\mathrm{UCH}$ work has been done on the response of organisms to light. 1 Naturally all of the earlier and a large part of the later work was qualitative in nature. Up to the time of Wiesner's classic work on heliotropism, no attempt had been made to express the photic sensibility of plants in quantitative terms. Since the publication of his 'Die heliotropischen Erscheinungen im Pflanzenreiche' (1879), little advance was made along quantitative lines until I909, when Blaauw published 'Die Perzeption des Lichtes'. In this important contribution modern physical methods are for the first time employed. The conclusions of Blaauw, however, are not in agreement with those of Wiesner, and both contradict without adequate explanation the results of the earlier investigators on phototropism, such as Gardner, Guillemin, Müller, and others.

While considerable progress has been made in the study of the threshold of stimulation-more especially as related to duration and intensity of the light stimulus-we have no complete record of the response of a given organism to carefully graded and measured light energies in the different spectral regions. 


\section{THEORIES OF RESPONSE.}

A number of theories of response based on the interpretation of data obtained by experimental methods have been formulated, and these shall be referred to as (I) Intensity difference, (2) Ray direction, (3) Wavelength, (4) Energy.

I. De Candolle ( $183^{2}$ ), the author of the 'intensity' theory, believed that, due to a difference in the light intensity upon the sides of the plant turned toward and away from the source of light, there results an increased carbon dioxide liberation and also an increased transpiration on the lighted side of the organism which brings about an earlier naturation of its cells and hardening of its tissues. Among the adherents to this theory, or to a more modern modification and interpretation of the same, may be mentioned Wiesner (1879), Darwin (I880), Engelmann (1883), Oltmanns (I892), Yerkes (1903), Loeb (1906), and Davenport (1907).

Wiesner attributes the response to the difference in the lighting of the two sides coupled with the inhibiting action of light. He argues that if the organ were entirely transparent and no light were lost by reflection, heliotropic response would be impossible. He offers no experimental proof in support of this view because, as he says, of the difficulty in measuring the difference in light intensity of the two sides.

Charles and Francis Darwin (I 880) concluded that the difference in the intensity of the light on opposite sides of the plant modifies the nutation and results in the tropic movement.

Engelmann (1883) found that a very gradual increase, or decrease, of light intensity produced no response in Paramecium bursaria. The same difference produced a response if the change took place rapidly. He concluded that response follows a time rate of change of intensity.

Loeb (1906) believes that because of the more intense light on one side of the organism there is produced a difference in chemical constitution of the cells on the two sides which results in heliotropic action.

Oltmanns (1892), by the use of India ink solutions in prismatic wedges, attempted to show that the response of the organism is due to a difference of intensity rather than to direction of ray. A later paper (1897) maintains that the intensity of the stimulus determines the direction, positive or negative, of the response of the organism.

2. Sachs $(1876)$ advanced the theory that the direction and degree of curvature is determined by the direction of the ray passing through the organism. The stimulus is perceived when the long axis of the organ forms an angle with the incident ray.

Strasburger (1878) added substantial proof to the ray-direction theory. By the response of the swarm-spores of Botrydium and Bryopsis in a trough behind a prismatic wedge filled with a solution of humic acid variously 
placed with reference to the light source, he concluded that the directive stimulus is due to the direction of the impinging ray rather than to light intensity. Davenport and Canon (I897) repeated the experiments of Strasburger, using a wedge-shaped container filled with India ink solution, and found that the direction taken by Daphnia was in the path of the light rays.

3. The relation between refrangibility and response was first attacked by Payer ( 1842 ), who used coloured glass screens spectroscopically tested. He found that cress seedlings behave in red, orange, yellow, and green as in total darkness, but respond positively in blue and violet, the blue being the more active.

Dutrochet ( 1844 ), using similar screens, found that cress seedlings failed to respond, but that other seedlings curve towards the red rays. His further experiments lead to the conclusion that response is not due to refrangibility, but to the 'brightness' of the light used.

The Italian botanist, Zantedeschi (1842), showed that Oxalis multifloris responds to blue, violet, and green, but not to yellow, orange, and red rays.

D. P. Gardner (1844) studied the effect of the various regions of the sun's spectrum, and concluded that rays of all refrangibility are capable of causing heliotropic response, but that the indigo rays had this property. to the highest degree. He decided that the intensity of light had only a subordinate influence, since by increasing the intensity the tropic response increased only slightly.

Guillemin (1858) exposed seedlings of cress and of mustard to the spectral regions obtained by passing the sun's rays through prisms of flint glass, of rock salt, and of quartz. His records show that heliotropic curvature is produced by the invisible chemical and heat rays, as well as by every region of the visible spectrum, as had previously been stated by Dutrochet and Puillet. He further found that the seedlings showed two maxima of response-one in the region between the violet and ultra-violet and the other between the infra-red and green. The positions of these maxima, however, shifted with a change of prisms, or with the position of the sun in the heavens, or with the water vapour in the air. The lower the position of the sun and the greater the amount of water vapour present in the air, the more the second maximum advanced into the visible regions. The more ready response in the violet which Dutrochet obtained, he explained as due to the absorption of the ultra-violet by the lenses used before the prism.

Sachs (1864), using coloured solutions, found heliotropic response only in the blue end of the spectrum. He made no attempt to secure pure colours or to measure the intensity of the light emitted.

Wiesner (1879), by the use of solutions, determined that seedlings of Vicia curved in all regions of the visible spectrum excepting in the yellow, which he found to exert a retarding action upon the effect of orange 
and red rays when mixed with them. Using the sun's spectrum, he obtained practically the same results. In both series of tests he found a first maximum between violet and ultra-violet, and a second between the red and infra-red. The effect decreased from either end of the spectrum to zero in the yellow.

Dandeno (1903) with glass filters obtained results which differ widely from those of the investigators already mentioned. He found a first maximum in yellow and a second in blue, with the minimum in green. His screens, when spectroscopically tested, did not give pure colour.

Sorokin (1873), Fischer von Waldheim (1872), and Brefeld (I88I), studied the effect of light passed through a solution of potassium bichromate, and an ammoniacal solution of copper oxide, on Pilobolus, reporting very different results. Thus Sorokin claims that Pilobolus fails to grow in light filtered through the solution of copper oxide and that it gives a negative response to light filtered through potassium bichromate. Fischer von Waldheim obtained a strong positive response to the blue light, while Brefeld had a positive reaction in both blue and red, especially strong in the red.

The divergent results of the investigators who have worked towards establishing a relation between refrangibility and response have been summarized by the author in Table I.

\section{TABLE I.}

Spectral regions.
Observer. Plant. Infra- Red. Orange. Yellow. Green. Bhue. Indigo. Violet. Ultra-
red.

\begin{tabular}{|c|c|c|c|c|c|c|c|c|c|c|}
\hline Payer (1842) & Cress & 0 & 0 & 0 & o & 0 & ++ & + & + & 0 \\
\hline Zantedeschi (I $84^{2}$ ) & Oxalis & 0 & 0 & o & 0 & + & + & + & + & o \\
\hline Dutrochet (1844) & Cress & 0 & 0 & 0 & 0 & & + & + & + & 0 \\
\hline Dutrochet (I 844) & $\begin{array}{l}\text { Other } \\
\text { seedlings }\end{array}$ & 0 & + & + & + & & + & + & + & 0 \\
\hline Gardner (I 844) & Rape & 0 & + & + & + & + & + & + & + & o \\
\hline Guillemin ( $\left.185^{8}\right)$ & Cress & + & ++ & + & + & + & + & + & + & ++ \\
\hline Sachs (I864) & Mustard & o & 0 & 0 & 0 & + & + & + & + & + \\
\hline Müller (I 872$)$ & Cress & & + & + & + & + & + & + & + & \\
\hline Sorokin $(1873)$ & Pilobolus & & - & - & - & & 0 & 0 & 0 & \\
\hline $\begin{array}{l}\text { Fischer von Wald- } \\
\text { heim }(1875)\end{array}$ & Pilobolus & & 0 & 0 & 0 & & + & + & + & \\
\hline Brefeld ( $188 \mathrm{I})$ & Pilobolus & & + & + & + & + & + & + & + & \\
\hline Wiesner (1879) & Vicia & + & + & + & - & + & + & + & ++ & + \\
\hline Gräntz (I 898) & Pilobolus & & + & + & + & + & + & + & + & + \\
\hline Dandeno (1903) & Seedlings & + & + & + & ++ & + & + & + & + & \\
\hline Blaauw (I909) & $\begin{array}{l}\text { Phyco- } \\
\text { myces }\end{array}$ & 0 & 0 & ० & + & + & + & ++ & + & + \\
\hline
\end{tabular}

The above summary shows the conflicting results obtained by a number of investigators on the response of plants to rays of light of different refrangibility.

$0=$ no response, + a positive, ++ maximum response, - negative response.

4. The attempts to correlate the heliotropic response in plants with an energy value of the light appears first in the work of N. J. C. Müller (I872). While experimenting with cress seedlings in the objective spectrum, he found 
that the maximum shifted in repeated experiments, and he concluded that the 'mechanical intensity' varied for one and the same colour. He believed that the blue-violet rays, because of their small intensity, were absorbed in the cells of the lighted side, hindering growth on that side. The longer waves, because of their greater energy, penetrated the tissue more deeply, having equal effect on the two sides, and no curvature resulted. He did not give further experimental proof of this theory.

Haberlandt (I902) developed a very interesting theory of response. $\mathrm{He}$ considered the epidermal cells as small lenses which focus the light rays upon the sensitive protoplasmic membranes of the underlying cells. Maxwell and Lebedev showed that light exerts a pressure approximately equivalent to $0.4 \mathrm{mg}$. to the square metre of absorbing surface, and Haberlandt suggests that the response is due to the presšure exerted by the light in a way somewhat similar to the response of a tendril when stimulated by a pressure equal to a weight of $0.0002 \mathrm{mg}$.

Wager (I909) modified Haberlandt's 'ocelli' theory in various ways. He believed that the effect of light is due to the absorbed rays in the colouring matter of the cells and not to a mechanical action upon the protoplasmic membranes. He found that the response/depends not upon the intensity of the light, but upon its quality, the more refrangible rays being the more active.

Radl (1903) had previously proposed a theory of photic response in animals somewhat similar to that of Haberlandt in plants. He believed that orientation was a direct reaction to light pressure, which, as he says, may resemble the pressure of an air-current.

Nathansohn and Pringsheim (1907) applied to reaction in plants the Talbot law which states that a definite quantity of light energy must be used to produce perceptible reaction. Pringsheim (I 912, p. I 57) found reaction to vary with phototropic attunement, or degree of adjustment in physiological condition according to the amount of light to which the plant was exposed previous to and during the period of one-sided illumination. In an earlier article (I909, p. 274) he stated that exact measurements in his experiments were impossible, since there was no method of expression for the value of the light source in definite units.

Blaauw (1909), by determining in photometric units the spectral regions, and calculating the energy values for each region from Langley's curve, attempted to explain the lack of harmony in the results of preceding investigators on the basis of energy distribution and of photo-chemical processes. From his experimental data on response of Avena and of Phycomyces in the spectral regions, he was able to construct curves consistent with those for visual sensitivity, but with the maxima located in the blue and indigo.

Clark (I9I3) gave remarkable results in his paper on negative photo- 
tropism in Avena sativa, in which he found that response takes place according to the Talbot law only in the so-called 'first positive' reaction, and that it does not follow the Talbot law in negative or in the 'second positive' reaction. He made no claim to definite values of intensity (p. 739), since he was unable to make exact photometric measurements.

Jennings (I906) and Verworn (I9I3) attribute response to a change in the physiological state in the organism. The physiological state depends upon metabolic processes which are influenced by external factors.

\section{Statement of Problem.}

From a consideration of the literature it is evident that the chief reason for the unsettled condition in regard to heliotropic response lies in the lack of accurate measurements of the quantity and quality of the light. The writer, by carefully measuring and calibrating the quality and intensity of the light stimulus, undertook the difficult task of correlating, if possible, the conflicting results and views held with reference to the nature of the light stimulus. This was attempted (I) by a study of the response of Pilobolus to carefully calibrated light of different wave-lengths and intensities, and (2) by a determination of the energy relation, if any, between this light and heliotropic response.

\section{MATERIALS AND METHODS.}

To determine the relative energy values in the different spectral regions it was necessary to employ very delicate physical instruments capable of calibration in standard units. A thermopile and galvanometer constructed by Professor W. W. Coblentz of the United States Bureau of Standards were used for this purpose. The thermopile was chosen because of its non-selective action in the different regions of the spectrum. The spectral regions used for experimental purposes were tested with a spectrometer from Adam Hilger and Co., London, and the limits of the wave-lengths determined. Cultures of Pilobolus, grown under controlled conditions and kept in absolute darkness for three hours preceding the formation of the sporangiophores, were exposed to these measured spectral regions, and the presentation time determined in each region. The threshold of stimulation thus found was taken as the measure of the sensitivity of Pilobolus to light of the different spectral regions.

The apparatus was of the type quite generally used in spectral experiments where artificial light is the source of illumination (Yerkes, I 9 Io, Laurens, I9II ; Day, I91 I ; Gross, I913). Two light-tight compartments $\left(a\right.$, Fig. I), each $270 \times 30 \times 30 \mathrm{~cm}$., were placed as wings at angles of $120^{\circ}$ to a middle compartment $(b), 120 \times 30 \times 30 \mathrm{~cm}$. The inside was blackened throughout with lampblack and provided. with screens $(c)$ to shut off 
all lateral radiation. In each end of the apparatus was a metal box $(d)$ with adjustable slit $(e)$ in which the light source was enclosed.

At $154 \mathrm{~cm} .\left(60^{\circ} 5 \mathrm{in}:\right)$ from the light source a lens (1), having a focal distance of $71^{\cdot} \cdot 2 \mathrm{~cm} .\left(28\right.$ in.), was placed. Seventy-nine $\mathrm{cm} .\left(3^{1} \cdot \mathrm{i}\right.$ in.) from each lens a carbon bisulphide prism (P) deflected a spectrum into the experimental chamber through adjustable slits in a screen $(m)$. It will be noted that the spectrum thrown on the screen was at twice the distance from the lens of that reported by Laurens, Day, and Gross. Much better spectral results were thus obtained. The thermopile (T) was connected in series with the galvanometer $(\mathrm{G})$, and deflexions of the galvanometer were read with telescope and scale at a distance of I metre. A tube $(n)$, with the inside completely blackened, led from the thermopile to the Hefner

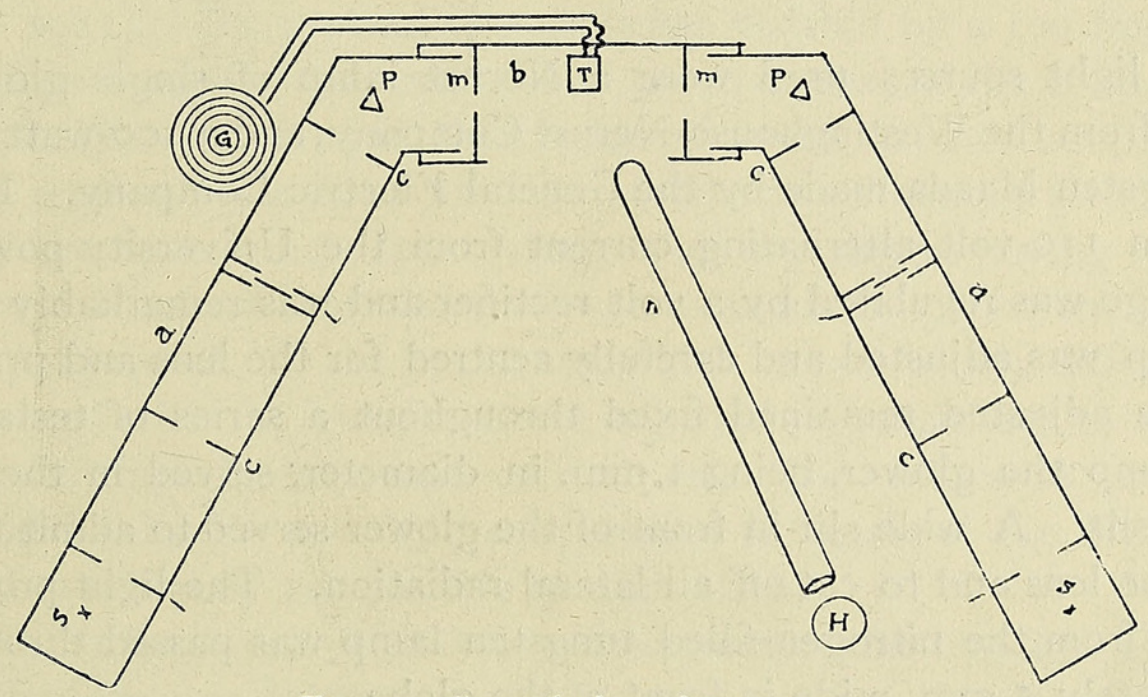

FIG. I. General plan of apparatus.

lamp $(\mathrm{H})$, and served to exclude all lateral radiation and draughts from the thermopile. This apparatus was located in a darkened basement room of the Natural History Building. The walls of this room were blackened, and all lights used in connexion with the apparatus were adjusted so that no stray rays could enter. The temperature and moisture conditions were comparatively constant. The room was thoroughly aired for two hours before each experiment.

The junctions of the thermopile were composed of bismuth and silver welded with tin and covered with platinum-black and lampblack. When a ray of light falls upon this surface at the junction of the two metals it is absorbed as heat and transformed by the junctions into electromotive force. A deflexion of the galvanometer in series with the thermopile indicates the intensity of the radiation. The galvanometer used to indicate the energy absorbed had a moving astatic system suspended by a fine quartz fibre. It was shielded from magnetic disturbance by tubes of soft iron having small apertures through which the scale reflected by the 
suspended mirror could be read. Small magnets placed near the galvanometer served to adjust its sensitiveness. The wires connecting the galvanometer to the thermopile were insulated and enclosed in a glass tube, which in turn was covered with tin-foil connected with the earth to prevent disturbances arising from slight variations of room temperature.

Much difficulty was to be anticipated in the manipulation and adjustment of instruments of such delicacy and precision. Although set up on a basement floor of heavy cement, the closing of doors in adjoining rooms or walking in the passage-ways caused tremors that interfered with galvanometer readings. Street cars passing a block away could be detected by a change in the sensitivity of the galvanometer. For these reasons the determinations were made at night and a time chosen when weather conditions were quiet and when very few people were working in the building.

The light sources used were a Nernst lamp of single glower type, obtained from the Westinghouse-Nernst Company, and a 200-watt nitrogenfilled tungsten Mazda made by the General Electric Company. Both were used on a Iro-volt alternating current from the University power plant. The voltage was regulated by a volt rectifier and was remarkably constant. Each lamp was adjusted and carefully centred for the lens and prism. The lamp once adjusted remained fixed throughout a series of tests. In the Nernst lamp the glower, being I mm. in diameter, served in the place of a narrow slit. A wide slit in front of the glower served to admit the direct light to the lens and to cut off all lateral radiation. The light projected on the prism from the nitrogen-filled tungsten lamp was passed through a slit approximately $5 \mathrm{~mm}$. wide in front of the globe.

The spectral region admitted to the experimental chamber was sufficiently large to cover the slit of the thermopile. Each region used was admitted through a separate slit $(2.5 \times 10 \mathrm{~mm}$.) cut in the slides of a photographic plate-holder. The frame for these holders was permanently attached to the base of the apparatus and the slide corresponding to the region to be studied was inserted at the focus of the rays for this region. The thermopile, when measurements were in progress, was placed at $10 \mathrm{~cm}$. from the slit.

The standard of light energy used was a Hefner lamp manufactured by Max Kohl and tested in the German Reichsanstalt. The conditions prescribed for its use were strictly followed, and it was placed at 2 metres from the thermopile, the latter enclosed in the experimental chamber. The energy value of this Hefner lamp at 2 metres distant from the thermocouple was determined in terms of the deflexion of the galvanometer. The energy of the light from any of the spectral regions from the different light sources was similarly read, and expressed in terms of the Hefner lamp reading. 


\section{Parr. - The Response of Pilobolus to Light.}

The mechanical value of radiation from the Hefner lamp burning under standard conditions as determined by Angstrom is $20^{\circ} 6 \times 10^{-8}$ $\frac{\text { sec. cm. }}{2}$ gr. cal. , or about 8.3 ergs (Nichols, 1905) per second per square centimetre at a distance of I metre (cf. Kniep and Minder, I909). At 2 metres the radiation has one-fourth of this value, or $2 \cdot 075$ ergs. Accordingly, whatever the sensitiveness of the galvanometer, the deflexion produced by the Hefner lamp under the given conditions is equivalent to 2.075 ergs. The energy values of the spectral regions used in the several experiments were measured and expressed as above indicated.

Since a galvanometer of the delicacy of the one used is subject to disturbance, its sensitivity was frequently tested, and if necessary it was readjusted by a slight change in the position of the controlling magnet (cf. Coblentz, I9II). To prevent the air being vitiated by a too frequent use of the Hefner lamp, the red, yellow, and green regions of the spectrum were very accurately determined in their relation to the Hefner lamp standard, and these regions were then used as standards of comparison for other regions of the spectrum. It is evident that any region having its energy value once determined may serve as such a standard. The energy values of the opposite ends of the spectrum, which are so widely different, were thus measured with the galvanometer adjusted in sensitivity to the region in which the experiments were carried on. The values in every case, as shown in Tables IV and V, are expressed in terms of the Hefner lamp values and are directly comparable to each other.

In the earlier work with the galvanometer the average of a series of ten deflexions was taken in each spectral region. It was subsequently found that three or four readings would give practically the same result, and, moreover, there was less chance for error arising from the change of magnetic and temperature conditions.

\section{Pilobolus.}

Pilobolus grows abundantly on manure obtained from the University dairy barns. Coemans (I859), Klein (I872), Brefeld (I88I), and others have described its culture and mode of growth. The sporangiophores late in the afternoon appear first at right angles to the substratum, due to a negative hydrotropism, and later grow vertical, due to negative geotropism (Pfeffer, 1906). At this stage the sporangiophores are extremely sensitive to light stimuli. In the evening the tips gradually grow into spherical yellow knobs, and the sensitivity of the sporangiophore is very much decreased (Jolivette, I9I4). During the night the sporangiophores become distended just below the yellow knobs, and the characteristic transparent bulbs are formed. In the morning the matured sporangia are projected with considerable force. 
A number of preliminary experiments were necessary to determine its behaviour under the normal laboratory conditions. It was found that the rapidity of sporangial development bears a direct relation to the temperature. At $28^{\circ} \mathrm{C}$. in the greenhouse sporangia are matured and projected early in the morning; at $20^{\circ} \mathrm{C}$. they are ejected at noon ; and at temperatures maintained below $8^{\circ} \mathrm{C}$. they are matured and ejaculated after four days.

It was noted that in direct light there is a tendency to earlier bulb formation than in the shadow, which is probably due to difference in transpiration (Lakon, 1907). Cultures which were well ventilated and kept in complete darkness developed sporangiophores of the usual length and ejected the sporangia but little later in the day than those grown in the same greenhouse in the light. Cultures kept in a laboratory where illuminating gas was used died out when windows were closed (cf. Crocker and Knight, 1908). In this series of experiments special care was taken to work in rooms free of gas.

Cultures of Pilobolus were grown in cases in the greenhouse at a relative humidity of 90 per cent. They were transferred early in the afternoon, before any tips were visible, to trays of moist sand and covered with earthen jars furnished with bent-pipe ventilator tubes. Late in the afternoon a culture was taken from the tray, revolved for one minute in a measured spectral region to attune all parts equally (Pringsheim, I9 I2, p. I 59 ; Clark, I9 I 3, p. 740), and then was exposed to one-sided illumination from this region for a definite period. During the exposure the culture rested on moist sand and was protected with a blackened shield to exclude stray light and to maintain the moisture conditions uniform. The moisture content of the air under the blackened shield as measured with Lambrecht's polymeter ranged between 85 and 92 per cent. relative humidity. The culture after exposure was returned to the tray and covered with the ventilated jar. After one hour it was examined with a reading glass and the number of curved sporangiophores recorded. Only cultures having sporangiophores with pointed tips were used. Strict observance of the physiological state was found necessary since a culture with swollen tips exposed for three hours to the green rays failed to respond, while one with pointed tips responded in seventy minutes. The time of presentation which was required to produce a curvature after a transmission time of one hour in approximately one-half the specimens in a culture, at the period of greatest sensitivity to stimuli, was taken as the standard for the measurement of the reaction of Pilobolus to light. No account was taken of reactions which occurred in extremely short intervals of time designated by Clark as 'first positive' curvatures. The longer intervals recorded in the following data without doubt correspond to those which he calls 'second positive' reactions. 
iV. Experimental Data and Results.

In Table II the measurements of wave-lengths as determined on a Hilger spectrometer for the Nernst and the nitrogen-filled tungsten Mazda lamps used in these experiments are given.

TABLE II.

Nernst.

\begin{tabular}{|c|c|c|c|c|}
\hline & & & & \\
\hline Colour. & $\begin{array}{l}\text { Included zuave- } \\
\text { lengths. }\end{array}$ & $\begin{array}{l}\text { Mean wave- } \\
\text { length. }\end{array}$ & $\begin{array}{l}\text { Included wave- } \\
\text { lengths. }\end{array}$ & $\begin{array}{l}\text { Mean wave- } \\
\text { length. }\end{array}$ \\
\hline Red & $\begin{array}{l}704 \\
712\end{array}$ & 708 & $\begin{array}{l}725 \\
691\end{array}$ & 708 \\
\hline ," & $\begin{array}{l}695 \\
638\end{array}$ & 667 & $\begin{array}{l}692 \\
635\end{array}$ & 666 \\
\hline Orange & $\begin{array}{l}647 \\
616\end{array}$ & $63 \mathrm{I}$ & $\begin{array}{l}653 \\
610\end{array}$ & ${ }^{63} \mathrm{I}$ \\
\hline " & $\begin{array}{l}660 \\
564\end{array}$ & 612 & $\begin{array}{l}640 \\
58 \mathrm{I}\end{array}$ & $61 \mathrm{I}$ \\
\hline Yellow & $\begin{array}{l}625 \\
553\end{array}$ & $5^{89}$ & $\begin{array}{l}603 \\
576\end{array}$ & $5^{89}$ \\
\hline$"$ & $\begin{array}{l}679 \\
551\end{array}$ & 585 & $\begin{array}{l}609 \\
55^{8}\end{array}$ & 583 \\
\hline Green & $\begin{array}{l}570 \\
510\end{array}$ & $54^{\circ}$ & $\begin{array}{l}55^{2} \\
525\end{array}$ & $53^{8}$ \\
\hline$"$ & $\begin{array}{l}543 \\
507\end{array}$ & 525 & $\begin{array}{l}542 \\
503\end{array}$ & 523 \\
\hline Blue & $\begin{array}{l}510 \\
4^{82}\end{array}$ & $49^{6}$ & $\begin{array}{l}570 \\
486\end{array}$ & $49^{8}$ \\
\hline " & $\begin{array}{l}479 \\
46 \mathrm{I}\end{array}$ & $47^{\circ}$ & $\begin{array}{l}49{ }^{\circ} \\
45^{6}\end{array}$ & 473 \\
\hline Indigo & $\begin{array}{l}47^{2} \\
45^{8}\end{array}$ & $4^{65}$ & $\begin{array}{l}468 \\
459\end{array}$ & $4^{6} 4$ \\
\hline " & $\begin{array}{l}444 \\
43^{2}\end{array}$ & $43^{8}$ & $\begin{array}{l}44^{2} \\
43^{I}\end{array}$ & 437 \\
\hline Violet & $\begin{array}{l}430 \\
408\end{array}$ & 414 & $\begin{array}{l}420 \\
410\end{array}$ & 415 \\
\hline$"$ & $\begin{array}{l}410 \\
385\end{array}$ & 398 & $\begin{array}{l}408 \\
388\end{array}$ & 398 \\
\hline
\end{tabular}

Table III gives the data for the galvanometer deflexions produced by the Hefner lamp at a distance of 2 metres, and for the red region of the Nernst lamp. The energy value of the red region of the Nernst lamp was calculated from the Angstrom value of the Hefner.

TABLE III.

\begin{tabular}{|c|c|c|c|c|c|}
\hline $\begin{array}{l}\text { Light } \\
\text { source. }\end{array}$ & Colour. & Wave-length. & $\begin{array}{l}\text { Gulvanometer deflexion } \\
\text { in } m m \text {. }\end{array}$ & $\begin{array}{l}\text { Average deflexion } \\
\text { in mm. }\end{array}$ & $\begin{array}{c}\text { Erosper } \\
\text { sec. per } \\
\mathrm{cm}^{2}\end{array}$ \\
\hline $\begin{array}{l}\text { Hefner } \\
\text { lamp }\end{array}$ & & $\begin{array}{l}\text { Total radiation } \\
\text { at } 2 \text { metres }\end{array}$ & $\begin{array}{l}540-70=40^{\circ} \\
530-90=44^{\circ} \\
510-70=44^{\circ} \\
520-70=45^{\circ}\end{array}$ & $45^{\circ}$ & 2.075 \\
\hline $\begin{array}{l}\text { Nernst } \\
\text { lamp }\end{array}$ & Red & \pm 667 & $\begin{array}{l}603-3^{6} 5=238 \\
595-35^{\circ}=245 \\
600-35^{\circ}=25^{\circ} \\
590-370=220\end{array}$ & 238 & 1.097 \\
\hline
\end{tabular}


Table IV gives the scale readings for the spectral regions of the Nernst lamp with the values expressed in ergs. The first determinations were made, using the energy value of wave-length \pm 667 equal to $\mathrm{x} .097$ ergs, found in Table III, as the standard of comparison. The energy value of wavelength \pm 540 equal to 0.344 ergs, as found in this determination, was then taken as the standard for following spectral regions. Another series of measurements is then recorded where the Hefner lamp at 2 metres serves as the direct standard. The results from the data here given are later summarized in Table IX.

TABLE IV.

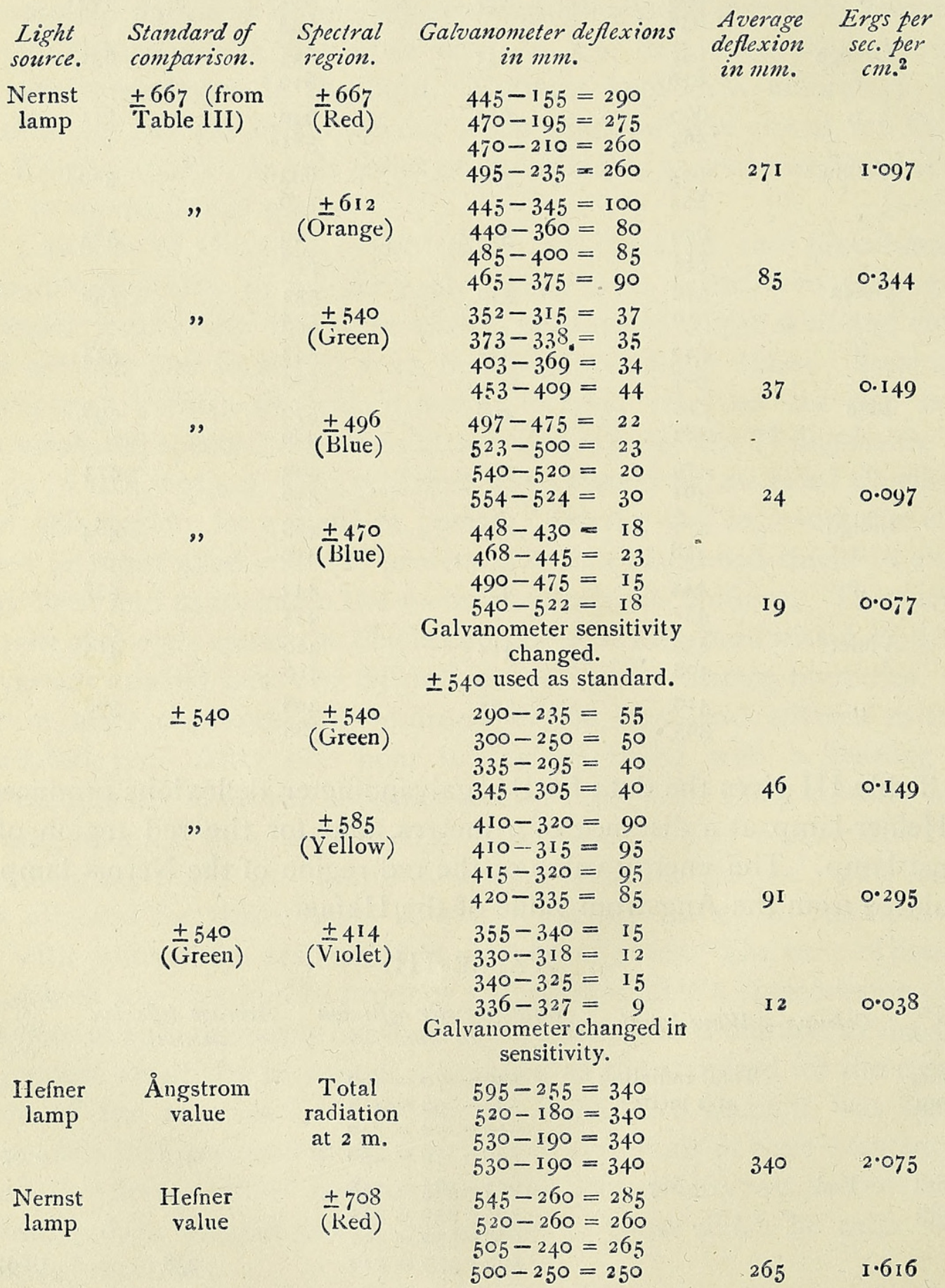




\begin{tabular}{|c|c|c|c|c|c|}
\hline $\begin{array}{l}\text { Light } \\
\text { source. }\end{array}$ & $\begin{array}{l}\text { Standard of } \\
\text { comparison. }\end{array}$ & $\begin{array}{l}\text { Spectral } \\
\text { region. }\end{array}$ & $\begin{array}{l}\text { Galvanomeler deflexions } \\
\text { in } \mathrm{mm} \text {. }\end{array}$ & $\begin{array}{l}\text { Average } \\
\text { deflexion } \\
\text { in mm. }\end{array}$ & $\begin{array}{l}\text { Ergs per } \\
\text { sec. per } \\
\mathrm{cm}^{2} .^{2}\end{array}$ \\
\hline \multirow[t]{6}{*}{$\begin{array}{l}\text { Nernst } \\
\text { lamp }\end{array}$} & $\begin{array}{c}\text { Hefner } \\
\text { value }\end{array}$ & $\stackrel{ \pm 6_{31}}{\text { (Orange) }}$ & $\begin{array}{l}245-140=105 \\
230-125=105 \\
235-120=115 \\
215-115=100\end{array}$ & 106 & 0.647 \\
\hline & $"$ & $\begin{array}{c} \pm 5^{89} \\
\text { (Yellow) }\end{array}$ & $\begin{array}{l}235-190=45 \\
240-185=55 \\
165-115=50 \\
175-125=50\end{array}$ & 50 & 0.305 \\
\hline & $"$ & $\left(\begin{array}{l} \pm 5^{23} \\
(\text { Green })\end{array}\right.$ & $\begin{array}{l}242-220=22 \\
270-249=21 \\
282-261=21\end{array}$ & $2 \mathrm{I}$ & 0.128 \\
\hline & $"$ & $\begin{array}{c} \pm 437 \\
\text { (Indigo) }\end{array}$ & $\begin{array}{l}310-302=8 \\
240-231=9 \\
200-191=9 \\
187-178=9\end{array}$ & 9 & 0.055 \\
\hline & $\pm 5^{23}$ & 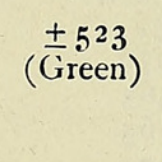 & $\begin{array}{l}255-195=60 \\
260-175=85 \\
230-155=75 \\
300-235=65\end{array}$ & $7 \mathrm{I}$ & 0.128 \\
\hline & $"$ & $\begin{array}{c} \pm 4^{6}{ }_{4} \\
\text { (Indigo) }\end{array}$ & $\begin{array}{l}375-345=30 \\
340-310=30 \\
330-285=40 \\
330-290=40\end{array}$ & 35 & 0.063 \\
\hline
\end{tabular}

Table $\mathrm{V}$ gives the galvanometer deflexions in the spectral regions of a 200-watt nitrogen-filled tungsten Mazda lamp as compared with those of the Hefner-the values being expressed in ergs. Since the spectrum of the tungsten lamp was but $8 \mathrm{~mm}$. in width and the slit of the thermopile I $8 \mathrm{~mm}$., a correction was necessary in order to make the readings comparable with those of the wider spectral regions of the Nernst lamp. The calculations for the energy values in red $( \pm 708)$ and yellow $( \pm 589)$ are made directly from comparison with the energy from the Hefner lamp. Other determinations were made and compared with the energy of the yellow region. These values are later summarized in Table IX.

\section{TABLE V.}

\begin{tabular}{|c|c|c|c|c|c|}
\hline $\begin{array}{l}\text { Light } \\
\text { source. }\end{array}$ & $\begin{array}{l}\text { Standard of } \\
\text { comparison. }\end{array}$ & $\begin{array}{l}\text { Spectral } \\
\text { region. }\end{array}$ & $\begin{array}{l}\text { Galvanometer deflex- } \\
\text { ions in } \mathrm{mm} \text {. }\end{array}$ & $\begin{array}{l}\text { Corrected deflex- } \\
\text { ion in mm. }\end{array}$ & $\begin{array}{l}\text { Ergs per sec. } \\
\text { per cm. }\end{array}$ \\
\hline \multirow[t]{2}{*}{$\begin{array}{l}\text { Hefner } \\
\text { lamp }\end{array}$} & $\begin{array}{l}\text { Ångstrom } \\
\text { value }\end{array}$ & $\begin{array}{l}\text { Total } \\
\text { radiation } \\
\text { at } 2 \mathrm{~m} \text {. }\end{array}$ & $\begin{array}{l}480-370=110 \\
485-360=125 \\
490-370=120 \\
500-3^{8} 5=115\end{array}$ & & \\
\hline & & & Average $=\overline{1 I \eta}$ & 117 & $2 \cdot 075$ \\
\hline \multirow[t]{4}{*}{$\begin{array}{l}\text { Tungsten } \\
\text { lampp }\end{array}$} & $\begin{array}{l}\text { Hefner } \\
\text { value }\end{array}$ & $\begin{array}{l} \pm 708 \\
(\text { Ked })\end{array}$ & $\begin{array}{l}55^{0}-350=200 \\
545-345=200 \\
540-340=200 \\
540-340=200\end{array}$ & & \\
\hline & & & Average $=\overline{200}$ & $45^{\circ}$ & $7 \cdot 980$ \\
\hline & $"$ & $\begin{array}{c}\stackrel{ \pm}{ \pm} 5^{89} \\
(\text { Yellow })\end{array}$ & $\begin{array}{l}504-440=64 \\
512-450=62 \\
522-460=62 \\
522-462=60\end{array}$ & & \\
\hline & & & Average $=\overline{\sigma_{2}}$ & 140 & $2 \cdot 480$ \\
\hline
\end{tabular}


Light Standard of Spectral source. comparison. region.

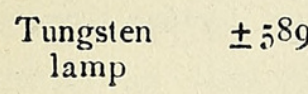

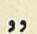

,

$\pm 589$

(Yellow)

$\pm 631$

(Orange)

$\pm 5^{89}$

(Yellow)

$$
\stackrel{+667}{(\text { Red })}
$$

$\because$

\pm 6 I 2

,

(Orange)

$\pm 5^{23}$

(Green)

18

ss

$\pm 4^{64}$
$($ Indigo

$\pm 437$

(Indigo)

"

, $\stackrel{+398}{\text { (Violet) }}$

")

$\pm 5^{39}$
Yellow)
Galvanometer deflexions in $\mathrm{mm}$.

Corrected deflexion in $m m$.

Ergs per sec.

Galvanometer changed in sensitivity.

$\mathrm{y} \pm 5^{89}$ used for com-

$$
\begin{gathered}
\text { parison. } \\
430-310=120 \\
450-330=120 \\
495-355=140 \\
520-380=140 \\
\text { Average }=130
\end{gathered}
$$

$440-130=310$

$430-135=295$

$445-130=315$

$435-\mathrm{I} .30=305$

Average $=305$

688

$5 \cdot 843$

Galvanometer changed

in sensitivity.

$400-230=170$

$405-240=165$

$425-260=165$

$435-260=175$

Average $=\overline{\mathrm{I} 69}$

378

$2 \cdot 480$

$610-225=385$

$610-215=395$

$580-190=390$

$590-195=395$

Average $=391$

879

$5 \cdot 760$

$438-2.32=206$

$445-2.38=207$

$495-275=220$

A verage $=211$

474

$3 \cdot 109$

$310-225=55$

$395-3 \mathrm{I} 5=$ 8००

$420-345=75$

$440-365=75$

Average $=7 \mathrm{I}$

162

$I \cdot 050$

$31_{5}-278=37$

$328-290=38$

$410-372=38$

$3^{8} 5-340=45$

Average $=\overline{39.5}$

$210-185=25$

$210-185=25$

$250-228=22$

$250-220=30$

Average $=\overline{25}$

56

0.364

$440-432=8$

$488-478=10$

$508-498=10$

$508-499=$

Average $=\frac{9}{9}$

Galvanometer changed in sensitivity.

$35^{8}-I_{2} 8=230$

$3^{6} 5-140=225$

$36_{5}-145=220$

A verage $=\overline{225}$ 
Light Standard of Spectral Galvanomeler deflex- Corrected deflex- Erosper sec. source. comparison. region. ions in mm. ion in $\mathrm{mm}_{\text {. }}$ per $\mathrm{cm}^{2}{ }^{2}$

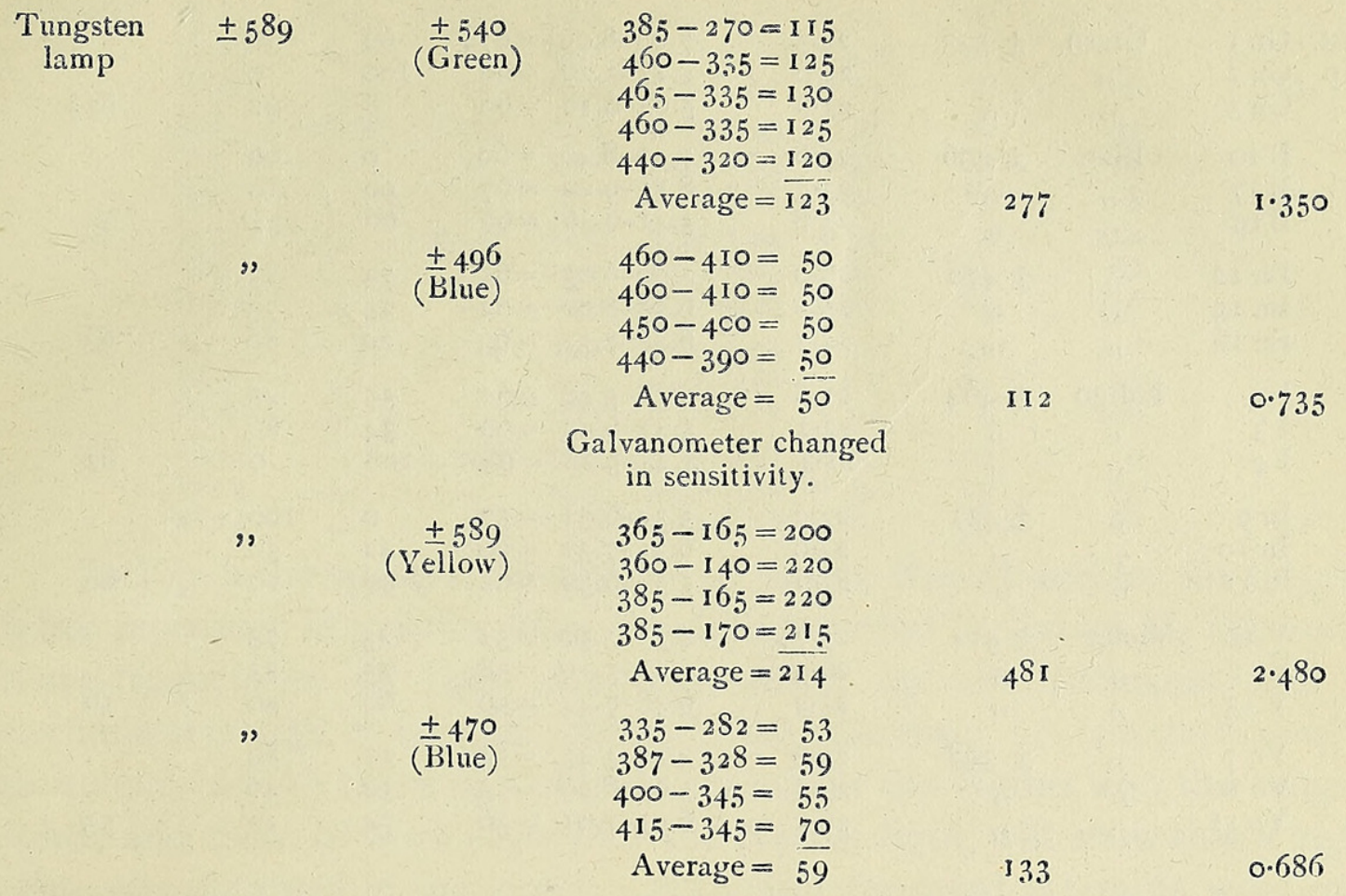

Tables VI and VII give the data for the determination of the presentation periods of Pilobolus in the different spectral regions. It was not deemed necessary to repeat here the periods of exposure longer and shorter than the ones which gave the final decisive results.

TABLE VI.

\begin{tabular}{|c|c|c|c|c|c|c|c|c|c|}
\hline \multirow{4}{*}{$\begin{array}{l}\text { Light } \\
\text { source. } \\
\text { Nernst } \\
\text { lamp }\end{array}$} & $\begin{array}{l}\text { Series } \\
\text { No. }\end{array}$ & Colour. & $\begin{array}{l}\text { Wave- } \\
\text { length. }\end{array}$ & Temp. ${ }^{\circ} \mathrm{C}$ & \multicolumn{2}{|c|}{$\begin{array}{l}\text { Time of exposure } \\
\text { in mins. }\end{array}$} & \multicolumn{2}{|c|}{$\begin{array}{l}\% \text { Posi- } \% \text { In- } \\
\text { tive. different. }\end{array}$} & $\begin{array}{l}\text { Presentat } \\
\text { time in } m\end{array}$ \\
\hline & & Red & \pm 708 & $24 \cdot 6$ & $6.55-7.33$ & $=78$ & 60 & $4^{\circ}$ & - \\
\hline & $\begin{array}{ll}\mathrm{Rn} 2 \\
\mathrm{Rn}\end{array}$ & $"$ & $"$ & $23 \cdot I$ & $4^{2} 3-5 \cdot 39$ & $\begin{array}{l}=76 \\
=80\end{array}$ & $\circ$ & 100 & \\
\hline & & & & & & & 93 & 7 & 78 \\
\hline & R I I & $"$ & \pm 667 & $24 \cdot 3$ & $6.13-7.28$ & $=75$ & $\circ$ & 100 & \\
\hline & R I 2 & $"$ & ", & $25 \cdot 7$ & $4.05-5.21$ & $=76$ & 88 & 12 & \\
\hline & $\mathrm{R}: 3$ & $"$ & ", & $24 \cdot 0$ & $4.04-5.21$ & $=77$ & 100 & o & 76 \\
\hline & On I & Orange & $\pm 63 \mathrm{I}$ & $24 \cdot 0$ & $4 \cdot 3^{6}-5 \cdot 5 \mathrm{I}$ & $=75$ & 64 & $4^{6}$ & \\
\hline & On 2 & $"$ & $"$ & $24 \cdot 0$ & $5.53-7.05$ & $=72$ & 0 & 100 & \\
\hline & On 3 & $"$ & $"$ & $25 \cdot 0$ & $4.55^{-6.12}$ & $=77$ & 90 & 10 & 75 \\
\hline & $\mathrm{O}_{3}$ & $"$ & \pm 612 & $26 \cdot 3$ & $5.56-7.08$ & $=72$ & $\begin{array}{r}0 \\
100\end{array}$ & 100 & \\
\hline & $\begin{array}{ll}O & 16 \\
O & 17\end{array}$ & $"$ & $"$ & $\begin{array}{l}24.5 \\
24.7\end{array}$ & $\begin{array}{l}4.18-5.33 \\
7.56-0.09\end{array}$ & $\begin{array}{l}=75 \\
=73\end{array}$ & $\begin{array}{r}100 \\
5^{2}\end{array}$ & $\begin{array}{r}0 \\
48\end{array}$ & \\
\hline & & & $"$ & & $7.50-9.09$ & $=73$ & $5^{2}$ & & 53 \\
\hline & Yn I & Yellow & \pm 589 & $24 \cdot 7$ & $4.18-5.30$ & $=72$ & 60 & 40 & \\
\hline & $\begin{array}{l}\text { In } 2 \\
\text { Yn } 3\end{array}$ & $"$ & $"$ & $24 \cdot 7$ & $5.12-6.22$ & $=70$ & 20 & so & \\
\hline & & & " & $25 \cdot 0$ & $45^{8-0.12}$ & $=74$ & 90 & 10 & 72 \\
\hline & $\begin{array}{ll}Y & 19 \\
Y & 20\end{array}$ & $"$ & $\pm 5^{8} 5$ & $24 \cdot 8$ & $7.55-9.05$ & $=70$ & o. & 100 & \\
\hline & $\begin{array}{l}Y 2.0 \\
Y 26\end{array}$ & $"$ & $"$ & $\begin{array}{l}24^{\cdot 8} \\
24.4\end{array}$ & $\begin{array}{l}6.01-7.15 \\
7.06-8.18\end{array}$ & $\begin{array}{l}=74 \\
=72\end{array}$ & $\begin{array}{r}100 \\
50\end{array}$ & ० & \\
\hline & G 8 & Green & \pm 540 & $24 \cdot 6$ & $7.50-0.00$ & & 100 & 0 & \\
\hline & G 10 & $"$ & $"$ & $26 \cdot 8$ & $6.51-7.56$ & $=65$ & 0 & 100 & \\
\hline & G I I & $"$ & $"$ & $24 \cdot 3$ & $5 \cdot 34-6.4^{2}$ & $=68$ & 33 & 66 & 69 \\
\hline
\end{tabular}


Light Series Colour. Wave- Temp. ${ }^{\circ}$ C. Time of exposure \% Posi- \% In. Presentation source. No. Colour. length. Temp. ${ }^{\circ} \mathrm{C}$. in mins. tive. different. time in min.

\begin{tabular}{|c|c|c|c|c|c|c|c|c|}
\hline $\begin{array}{c}\text { Nernst } \\
\text { lamp }\end{array}$ & $\begin{array}{l}\text { Gn I } \\
\text { Gn } 2 \\
\text { Gn } 3\end{array}$ & $\begin{array}{c}\text { Green } \\
, "\end{array}$ & $\begin{array}{c} \pm 5^{2} 3 \\
", \\
",\end{array}$ & $\begin{array}{l}24.5 \\
24.0 \\
23.6\end{array}$ & $\begin{array}{l}7.02-8.09 \\
4.17-5.26 \\
5.04-6.10\end{array}$ & $\begin{array}{l}=67 \frac{1}{2} \\
=69 \\
=66\end{array}$ & $\begin{array}{r}62 \\
100 \\
8\end{array}$ & $\begin{array}{r}38 \\
\circ \\
92\end{array}$ \\
\hline . & $\begin{array}{l}\text { B } 10 \\
\text { B I } 7 \\
\text { B } 19\end{array}$ & $\begin{array}{c}\text { Blue } \\
", \\
",\end{array}$ & $\begin{array}{c} \pm 49^{6} \\
",\end{array}$ & $\begin{array}{l}23.6 \\
23.7 \\
24.8\end{array}$ & $\begin{array}{l}7.40-8.40 \\
8.15-9.22 \\
5.4 \mathrm{I}-6.46\end{array}$ & $\begin{array}{l}=60 \\
=67 \\
=66\end{array}$ & $\begin{array}{r}\circ \\
90^{\circ} \\
66\end{array}$ & $\begin{array}{r}100 \\
10 \\
34\end{array}$ \\
\hline & $\begin{array}{l}\text { Bn } 12 \\
\text { Bn } 13 \\
\text { Bn } 16\end{array}$ & ", & $\begin{array}{c} \pm 470 \\
, " \\
, "\end{array}$ & $\begin{array}{l}26.0 \\
26 \cdot 0 \\
24.7\end{array}$ & $\begin{array}{l}5.00-6.05 \\
6.5^{8-8.00} \\
6.4^{8-7.5}\end{array}$ & $\begin{array}{l}=65 \\
=62 \\
=63\end{array}$ & $\begin{array}{l}75 \\
25 \\
20\end{array}$ & $\begin{array}{l}25 \\
75 \\
80\end{array}$ \\
\hline & $\begin{array}{l}\text { I } 2 \\
\text { I } 3 \\
\text { I } 4\end{array}$ & $\begin{array}{c}\text { Indigo } \\
, " \\
, "\end{array}$ & $\begin{array}{c} \pm 46_{4} \\
", \\
",\end{array}$ & $\begin{array}{l}23 \cdot 8 \\
23 \cdot 2 \\
23 \cdot 4\end{array}$ & $\begin{array}{l}4 \cdot 38-5 \cdot 40 \\
5 \cdot 4^{2}-6.4^{2} \\
4.24-5.28\end{array}$ & $\begin{array}{l}=62 \\
=60 \\
=64\end{array}$ & $\begin{array}{r}55 \\
34 \\
100\end{array}$ & $\begin{array}{r}45 \\
66 \\
0\end{array}$ \\
\hline & $\begin{array}{l}\text { In } 9 \\
\text { In } 10 \\
\text { In II }\end{array}$ & $\begin{array}{l}", \\
",\end{array}$ & $\begin{array}{c} \pm 437 \\
", \\
",\end{array}$ & $\begin{array}{l}24 \cdot 7 \\
24 \cdot 6 \\
23 \cdot 6\end{array}$ & $\begin{array}{l}5.34^{-6.31} \\
6.32-7.32 \\
5.54^{-6.56}\end{array}$ & $\begin{array}{l}=57 \\
=60 \\
=62\end{array}$ & $\begin{array}{r}0 \\
42 \\
90\end{array}$ & $\begin{array}{r}100 \\
58 \\
10\end{array}$ \\
\hline & $\begin{array}{ll}V & \text { I0 } \\
V & 112 \\
V & 12\end{array}$ & $\begin{array}{c}\text { Violet } \\
, " \\
, "\end{array}$ & $\begin{array}{c} \pm 4^{\mathrm{I}} 4 \\
, "\end{array}$ & $\begin{array}{l}25 \cdot 7 \\
24 \cdot 3 \\
25 \cdot 2\end{array}$ & $\begin{array}{l}4 \cdot 5^{8}-5 \cdot 50 \\
4.2 \mathrm{I}-5 \cdot 19 \\
6.4^{8}-7 \cdot 44\end{array}$ & $\begin{array}{l}=52 \\
=58 \\
=56\end{array}$ & $\begin{array}{l}25 \\
75 \\
60\end{array}$ & $\begin{array}{l}75 \\
25 \\
40\end{array}$ \\
\hline & $\begin{array}{l}\text { Vn } 7 \\
\text { Vn Io } \\
\text { Vn I I }\end{array}$ & " & $\begin{array}{c} \pm 39 S \\
, "\end{array}$ & $\begin{array}{l}25 \cdot 6 \\
26 \cdot 5 \\
26 \cdot 5\end{array}$ & $\begin{array}{l}4.49-5.43 \\
5.05-6.00 \\
6.05-7.01\end{array}$ & $\begin{array}{l}=54 \\
=5.5 \\
=56\end{array}$ & $\begin{array}{l}\text { I I } \\
54 \\
74\end{array}$ & $\begin{array}{l}89 \\
46 \\
26\end{array}$ \\
\hline
\end{tabular}

\section{TABLE VII.}

Light Series Colour. Wave- Temp. Time of exposure \% Posi- \% Indif- Presentalion
source. No.

\begin{tabular}{|c|c|c|c|c|c|c|c|c|c|}
\hline \multirow[t]{9}{*}{$\begin{array}{l}\text { Tungsten } \\
\text { lamp }\end{array}$} & $\begin{array}{l}\text { Rt } 2 \\
\text { Rt } 3 \\
\text { Rt } 4\end{array}$ & $\begin{array}{l}\text { Red } \\
",\end{array}$ & $\begin{array}{c} \pm 708 \\
, " \\
",\end{array}$ & $\begin{array}{l}26 \cdot 6 \\
24 \cdot 0 \\
26 \cdot 4\end{array}$ & $\begin{array}{l}6.32-7 \cdot 37 \\
6.39-7 \cdot 47 \\
4.27-5 \cdot 3^{6}\end{array}$ & $\begin{array}{l}=65 \\
=68 \\
=69\end{array}$ & $\begin{array}{r}0 \\
50 \\
7 \mathrm{I}\end{array}$ & $\begin{array}{r}100 \\
50 \\
29\end{array}$ & 68 \\
\hline & $\begin{array}{l}\operatorname{Ra} 6 \\
\operatorname{Ra} 7 \\
\operatorname{Ra} 8\end{array}$ & ", & $\begin{array}{c} \pm 667 \\
" \prime\end{array}$ & $\begin{array}{l}23^{\circ} 4 \\
23^{\circ} 0 \\
25^{\circ} \cdot 6\end{array}$ & $\begin{array}{l}5.36-6.4^{2} \frac{1}{2} \\
6.4^{6-7.50} \\
4 \cdot 4^{8}-5 \cdot 56\end{array}$ & $\begin{array}{l}=66 \frac{1}{2} \\
=64 \\
=68\end{array}$ & $\begin{array}{l}57 \\
15 \\
95\end{array}$ & $\begin{array}{r}43 \\
85 \\
5\end{array}$ & $66 \frac{1}{2}$ \\
\hline & $\begin{array}{l}\text { Ot } 3 \\
\text { Ot } 4 \\
\text { Ot } 5\end{array}$ & $\begin{array}{c}\text { Orange } \\
", \\
",\end{array}$ & $\begin{array}{c} \pm 63 \mathrm{I} \\
" \Longrightarrow\end{array}$ & $\begin{array}{l}25 \cdot 8 \\
25 \cdot 8 \\
25 \cdot 9\end{array}$ & $\begin{array}{l}4.5^{8-6.02 \frac{1}{2}} \\
6.04-7.10 \\
7.12-8.14\end{array}$ & $\begin{array}{l}=64 \frac{1}{2} \\
=66 \\
=62\end{array}$ & $\begin{array}{l}5^{\circ} \\
70 \\
3^{6}\end{array}$ & $\begin{array}{l}50 \\
30 \\
64\end{array}$ & $6_{4} \frac{1}{2}$ \\
\hline & $\begin{array}{l}\text { Oa } 1 \\
\text { Oa } 2 \\
\text { Oa } 3\end{array}$ & ", & $\begin{array}{c} \pm 612 \\
",\end{array}$ & $\begin{array}{l}24^{\cdot 6} \\
23^{\cdot} \cdot 1 \\
23^{\cdot 2}\end{array}$ & $\begin{array}{l}6.17-7.21 \\
4.20-5.26 \\
5.27-6.29\end{array}$ & $\begin{array}{l}=64 \\
=66 \\
=62\end{array}$ & $\begin{array}{r}50 \\
100 \\
25\end{array}$ & $\begin{array}{r}50 \\
\circ \\
75\end{array}$ & 64 \\
\hline & $\begin{array}{l}\mathrm{Yt}_{4} \\
\mathrm{Yt} 8 \\
\mathrm{Yt} 9\end{array}$ & $\begin{array}{c}\text { Yellow } \\
",\end{array}$ & $\begin{array}{c} \pm 5^{89} \\
" \%\end{array}$ & $\begin{array}{l}23^{\circ} 6 \\
25^{\circ} 0 \\
24^{\circ} 4\end{array}$ & $\begin{array}{l}6.00-7.01 \\
6.05-7.09 \\
7.11-8.14\end{array}$ & $\begin{array}{l}=61 \\
=64 \\
=63\end{array}$ & $\begin{array}{r}0 \\
75 \\
75\end{array}$ & $\begin{array}{r}100 \\
25 \\
25\end{array}$ & $\sigma_{3}$ \\
\hline & $\begin{array}{l}\text { Ya I } 2 \\
\text { Ya I } 3 \\
\text { Ya I } 4\end{array}$ & " & $\begin{array}{c} \pm 5^{8} 5 \\
", \\
",\end{array}$ & $\begin{array}{l}24 \cdot 8 \\
25 \cdot 2 \\
25 \cdot 7\end{array}$ & $\begin{array}{l}6.12-7.15 \\
4.54-5.59 \\
5.50-6.52\end{array}$ & $\begin{array}{l}=63 \\
=65 \\
=62\end{array}$ & $\begin{array}{l}42 \\
90 \\
10\end{array}$ & $\begin{array}{l}5^{8} \\
10 \\
90\end{array}$ & 63 \\
\hline & $\begin{array}{l}\text { Ga } 1 \\
\text { Ga } 2 \\
\text { Ga } 3\end{array}$ & $\begin{array}{c}\text { Green } \\
", \\
",\end{array}$ & $\begin{array}{c} \pm 540 \\
, " \\
,\end{array}$ & $\begin{array}{l}21 \cdot 5 \\
21 \cdot 5 \\
24^{\circ} 0\end{array}$ & $\begin{array}{l}6.33-7.33 \\
7.34-8.32 \\
4.24-5.26\end{array}$ & $\begin{array}{l}=60 \\
=5^{8} \\
=62\end{array}$ & $\begin{array}{r}45 \\
37 \\
100\end{array}$ & $\begin{array}{r}55 \\
63 \\
0\end{array}$ & 60 \\
\hline & $\begin{array}{l}\text { Gt } 3 \\
\text { Gt } 4 \\
\text { Gt } 8\end{array}$ & ", & $\begin{array}{c} \pm 5^{23} \\
" \prime \\
" 1\end{array}$ & $\begin{array}{l}26 \cdot 0 \\
24^{\circ} 9 \\
24^{\circ} 6\end{array}$ & $\begin{array}{l}6.54-7.57 \\
7.06-8.04 \\
5.44-6.44\end{array}$ & $\begin{array}{l}=63 \\
=58 \\
=60\end{array}$ & $\begin{array}{r}71 \\
0 \\
82\end{array}$ & $\begin{array}{r}29 \\
100 \\
18\end{array}$ & 59 \\
\hline & $\begin{array}{l}\mathrm{Ba} 7 \\
\mathrm{Ba} 8 \\
\mathrm{Ba} \text { I I }\end{array}$ & $\begin{array}{l}\text { Blue } \\
",\end{array}$ & $\begin{array}{c} \pm 49^{6} \\
",\end{array}$ & $\begin{array}{l}23 \cdot 6 \\
24 \cdot 0 \\
26 \cdot 0\end{array}$ & $\begin{array}{l}5.06-6.05 \\
6.15-7.11 \\
4.35-5.3^{2}\end{array}$ & $\begin{array}{l}=59 \\
=56 \\
=57\end{array}$ & $\begin{array}{l}67 \\
20 \\
56\end{array}$ & $\begin{array}{l}34 \\
80 \\
44\end{array}$ & 57 \\
\hline
\end{tabular}




\begin{tabular}{|c|c|c|c|c|c|c|c|c|c|}
\hline \multirow{15}{*}{$\begin{array}{l}\text { Light } \\
\text { source. } \\
\text { Tungsten } \\
\text { lamp }\end{array}$} & $\begin{array}{l}\text { Series } \\
\text { No. }\end{array}$ & & $\begin{array}{l}\text { Wave- } \\
\text { length. }\end{array}$ & $\begin{array}{l}\text { Temp. } \\
{ }^{\circ} \mathrm{C} .\end{array}$ & $\begin{array}{l}\text { Time of ex } \\
\text { in min }\end{array}$ & $\begin{array}{l}\text { xposure } \\
\text { in. }\end{array}$ & $\begin{array}{l}\% \text { Posi- } \\
\text { tive. }\end{array}$ & $\begin{array}{l}\% \text { Indif- } \\
\text { ferent. }\end{array}$ & $\begin{array}{l}\text { Presentation } \\
\text { time in min. }\end{array}$ \\
\hline & Bt 9 & Blue & \pm 470 & $24 \cdot 7$ & $5.37-6.30$ & $=53$ & 20 & 80 & \\
\hline & Bt 10 & $"$ & $"$ & 23.6 & $4 \cdot 4^{6}-5 \cdot 4^{\mathrm{I}} \frac{\mathrm{I}}{2}$ & $=55 \frac{1}{2}$ & 94 & 6 & \\
\hline & Bt I I & & & & & & 37 & 63 & 55 \\
\hline & $\begin{array}{l}\text { It } 6 \\
\text { It } 7\end{array}$ & Indigo & $\begin{array}{c} \pm 4^{6} 4 \\
y\end{array}$ & $\begin{array}{l}24 \cdot 3 \\
24 \cdot 8\end{array}$ & $\begin{array}{l}5 \cdot 45-643 \\
4 \cdot 38-5.33\end{array}$ & $\begin{array}{l}=58 \\
=55\end{array}$ & $\begin{array}{l}66 \\
60\end{array}$ & $\begin{array}{l}33 \\
40\end{array}$ & \\
\hline & It 8 & $"$ & $"$ & $25^{\circ} 2$ & $6.45-7.35$ & $=50$ & 25 & 75 & 55 \\
\hline & Ia 3 & $"$ & \pm 437 & $24 \cdot 9$ & $6.34-7.24$ & $=50$ & 0 & 100 & \\
\hline & Ia 9 & $"$ & $"$ & $25 \cdot 2$ & $7.09-8.03$ & $=54$ & $3^{2}$ & 68 & \\
\hline & la 10 & & $"$ & $24^{\circ} 0$ & $4 \cdot 45-5 \cdot 4^{2}$ & $=57$ & 84 & 16 & 54 \\
\hline & $\mathrm{Va} I$ & Violet & $\pm 4^{14}$ & $25 \cdot 2$ & $5.00-5.53$ & $=53$ & $9^{2}$ & 8 & \\
\hline & Va 5 & $"$ & $"$ & $25 \cdot I$ & $5.21-6.12$ & $=5 \mathrm{I}$ & 50 & 50 & \\
\hline & Va 6 & $"$ & $"$ & $25 \cdot 3$ & $6.12-7.02$ & $=50$ & 0 & 100 & $5^{I}$ \\
\hline & Vt I 2 & $"$ & $\pm 39^{8}$ & $25^{\cdot 2}$ & $3.59-4.5^{8}$ & $=59$ & 100 & 0 & \\
\hline & Vt I3 & $"$ & $"$ & $23 \cdot 5$ & $5.05-5 \cdot 5^{2}$ & $=52$ & 25 & 75 & \\
\hline & Vt I 4 & " & ", & $23^{\circ} 8$ & $5.37-6.27$ & $=50$ & 33 & 66 & 50 \\
\hline
\end{tabular}

In Fig. 2 the spectral energy curves for the Nernst and for the tungsten lights represent in graphic form the data recorded in Tables II, IV, and V. Wave-frequencies of light are represented by the ordinates and the mechanical energy in ergs per second by the abscissae. A comparison of the above curves with those of Coblentz (I9II) for the Nernst and the tungsten lights, and those of Moll (1907) for the Nernst light, will show that a higher value was obtained in the violet. Although repeated attempts were made to bring these results in the violet into conformity with those of Coblentz and Moll, they were not successful. The difference may be in part due to the use of the Nernst lamp with the globe removed.

A number of investigators have maintained that the response of organisms to light of different nature may be correlated with energy equivalence. Pilobolus, exposed to the spectral regions of the Nernst and tungsten lamps differing rather widely in energy, will respond as indicated in Fig. 3. In plotting these graphs the wave-lengths and frequencies are disregarded. The abscissae represent the presentation time and the ordinates the energy of the region expressed in ergs, the data being taken from Tables IV, V, VI, and VII.

An inspection of Fig. 3 shows that an actual decrease in the rate of response takes place with increase of the photic energy. This shows, conclusively, there is no direct relation between response and the energy of the different regions. Thus, the lens theory of Haberlandt (1905) and the orientation theory of Radl (1903), that response is due to a pressure that the light exerts on the cells of the organ, are not applicable to the response of Pilobolus.

Likewise, a statement in Blaauw's theory of response (1909, p. 30), namely, that the plant perceives only the quantity of energy as a stimulus, cannot be taken literally, for he says: 'Für diesen konstanten Effekt ist eine konstante Quantität Energie nötig und es ist also für die Pflanze gleichgültig, wie diese Energie, über Zeit und Intensität verteilt, zugeführt wird. Die Pflanze empfindet nur die Quantität Energie als Reiz; die 
Zeit und die Intensität sind nichts mehr als Faktoren von der Energiemasse. Nur diese Quantität Energie wirkt als Reiz, für die Pflanze selbst besteht weder die Intensität, noch die Zeit als eine absonderliche Grösse.' Fröschel (1909, p. 422) expresses the same view in different words, thus: 'Gleiche

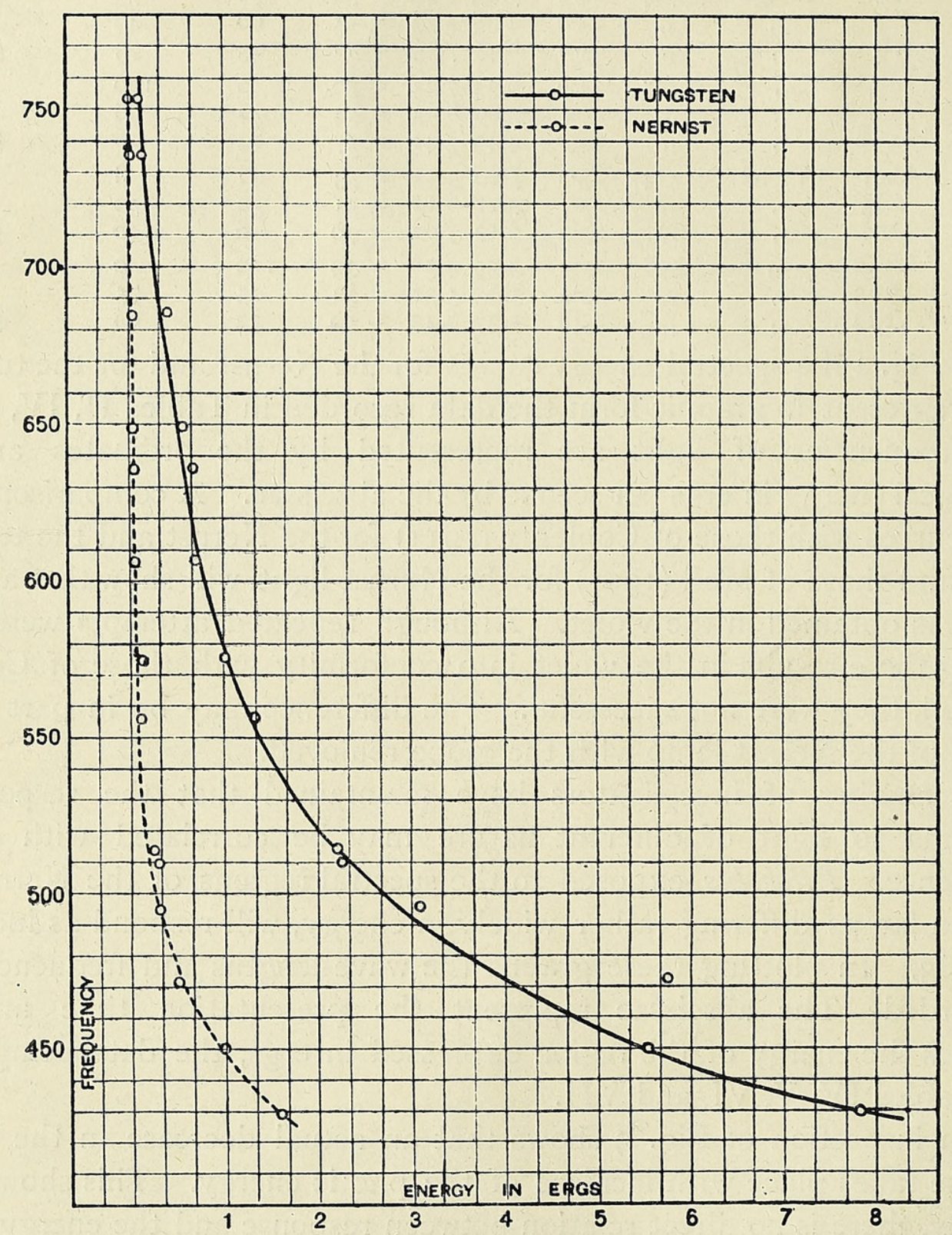

FIg. 2. Spectral energy graphs (from data in Tables II, IV, and V) for the single glower Nernst lamp and the 200-watt nitrogen-filled tungsten Mazda lamp used in these experiments. Ordinates represent wave-frequencies of light and abscissae the mechanical energy in ergs per second per square centimetre.

Energiemengen rufen bei Pflanzen gleiche Reaktionen, beim menschlichen Auge gleiche Empfindungen hervor.'

A superficial study of these curves, however, might lead one to the erroneous belief that increase of energy has an inhibiting effect on the tropic response. If this were true, the decrease in the irritability in the tungsten light towards the higher energy values would be much more rapid 


$$
\text { Parr.-The Response of Pilobolus to Light. }
$$

than in those of the Nernst. Further discussion of the energy relation will be taken up later.

If the presentation periods be plotted with reference to frequency of the light waves in the spectral regions to which Pilobolus was exposed, the results will appear as in Fig. 4. These graphs are based on the data given

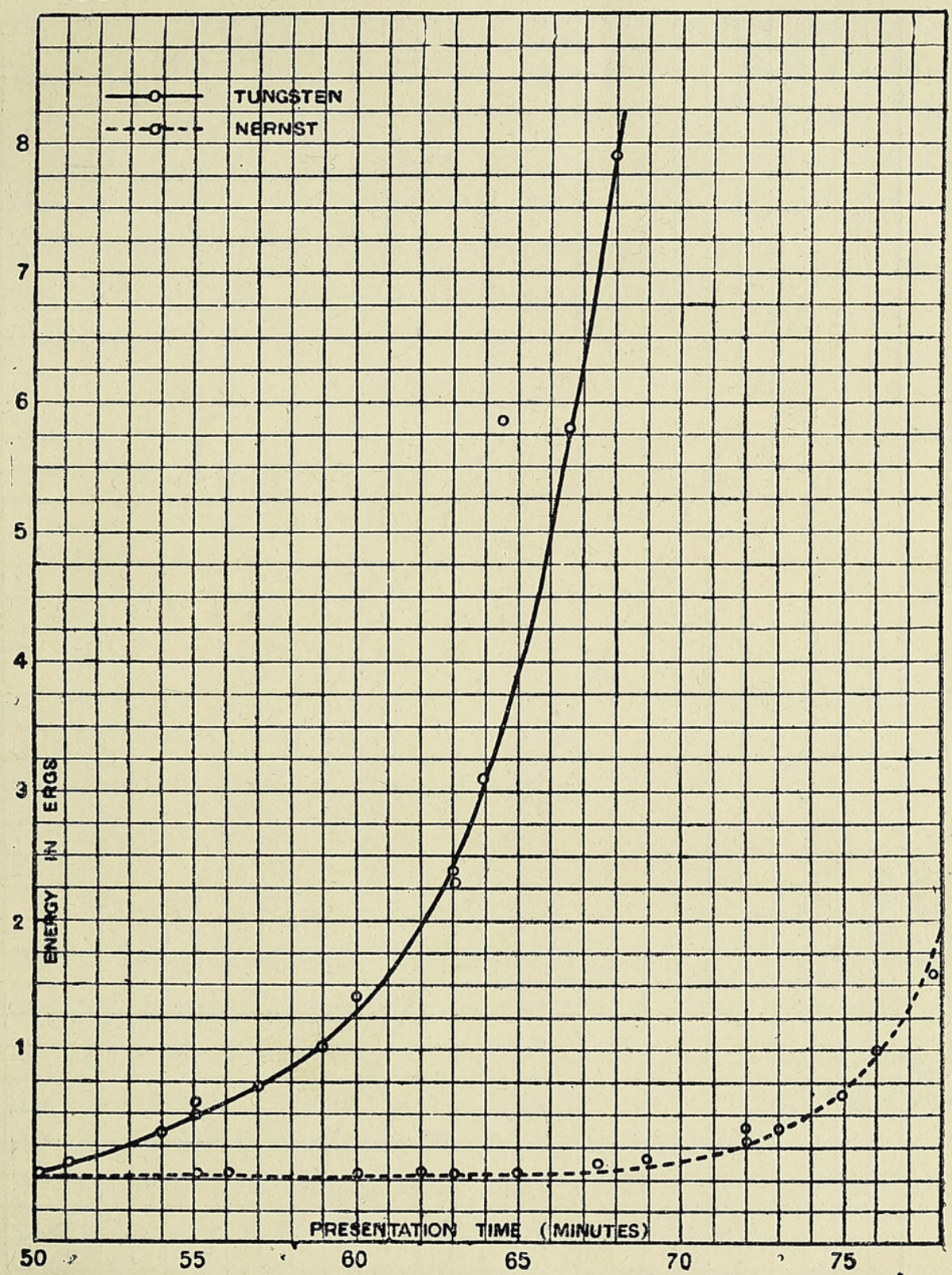

FIG. 3. Graphs (from data in Tables IV, V, VI, and VII) in which abscissae represent the presentation time of Pilobolus and ordinates the energy values of the spectral regions to which the plant was exposed.

in Tables II, VI, and VII. In this instance it will be noted that response in Pilobolus takes place in every region of the spectrum, and that the presentation period decreases from red to violet, or conversely, that the irritability increases from red to violet. These results then confirm those obtained by Brefeld (I88I, p. 60) and Gräntz (I 898 ), and are contrary to those of Sorokin (I874) and of Fischer von Waldheim (1875).

The graphs as given in Fig. 4 are remarkably constant in their gradual 
increase from red to violet. At no time was there found in this series of experiments any intermediate minimum such as Wiesner obtained in yellow (1879) and Dandeno in green (1903), nor a maximum, as reported by Guillemin ( 1857 ) in the violet and in the red, by Dandeno in yellow, and by Blaauw (1909) in indigo.

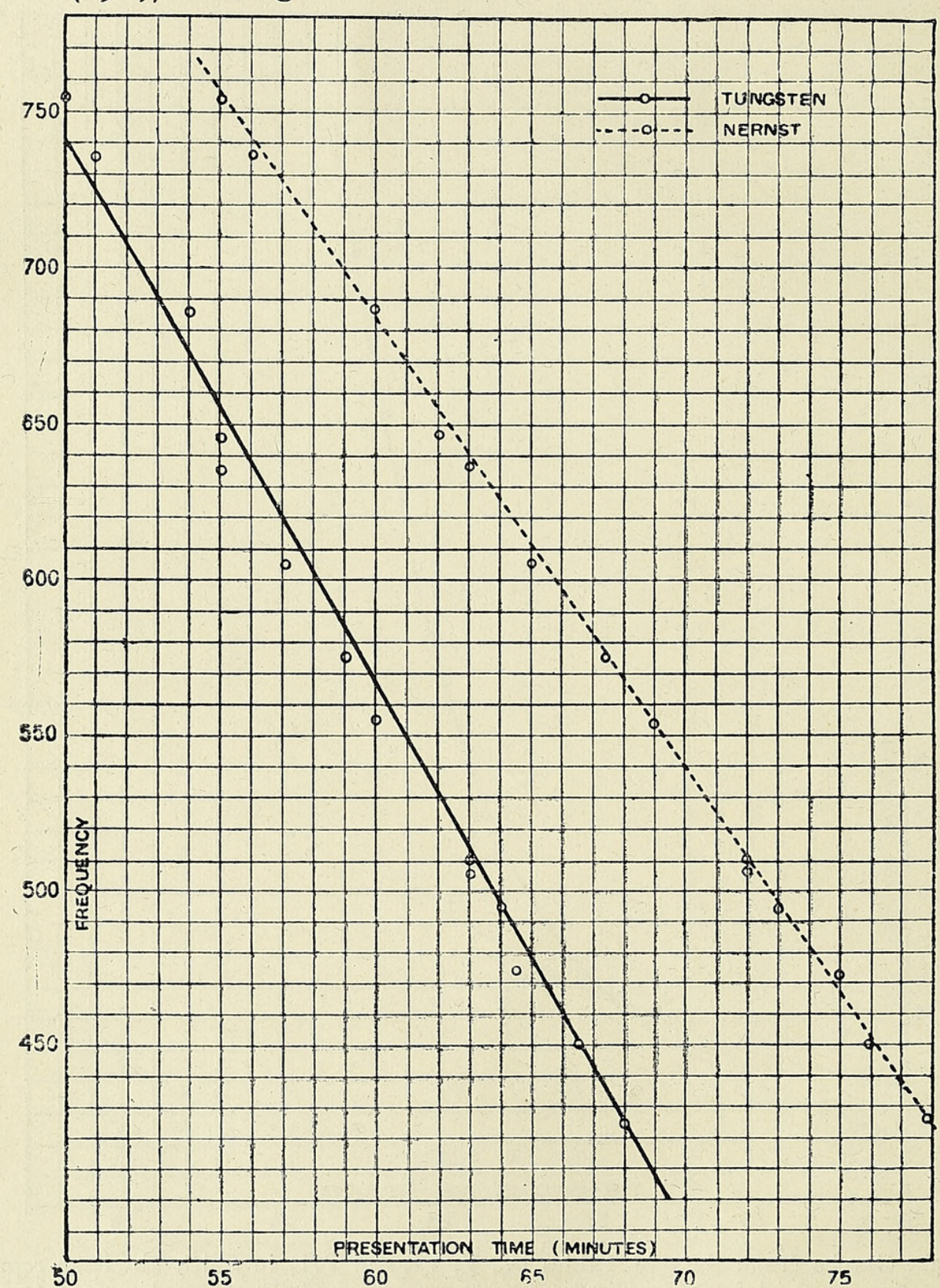

FIG. 4. Graphs (from data in Tables II, VI, and VII) showing presentation times on Pilobolus in relation to frequency of light waves. Abscissae represent the presentation times in minutes, and ordinates the frequency of the light waves.

The slope of the graphs from the violet towards the red shows that the response of the organism has a very marked relation to wave-frequency. Calculation of this relation shows that the product of the square root of the frequencies and the presentation time is so nearly uniform as to warrant attention later (cf. Nernst, I899; Verworn, I9I3). The results of this calculation are given in Table VIII. 
Attention must be called to the fact that the graphs representing the time and frequency relation (Fig. 4) of Pilobolus for the two sources of light (Nernst and tungsten) are not nearly identical, as would be the case were wave-frequencies alone responsible for the differences in the induction periods. Furthermore, the two graphs diverge somewhat from the violet towards the red, giving additional evidence that energy is a factor in the relative time required for phototropic excitation. The fact that energy does play a part in response is further manifest from the results given in Table VIII. This table shows that while the square roots of the frequencies constitute an ascending series, the square roots of the presentation times form a slightly descending series. It should also be noted that the constant for the Nernst is considerably larger than that for the tungsten.

\section{TABLE VIII.}

\begin{tabular}{|c|c|c|c|c|c|c|c|}
\hline Colour. & $\begin{array}{l}\text { Wave- } \\
\text { length. }\end{array}$ & Frequency. & $\sqrt{f .}$ & $\begin{array}{l}\text { Nerns } \\
\text { Presentation } \\
\text { time in min. }\end{array}$ & $\sqrt{f \times} t$. & $\begin{array}{l}\text { Tuns } \\
\text { Presentation } \\
\text { time in min. }\end{array}$ & $\sqrt{f \times} \times$. \\
\hline Red & \pm 708 & \pm 424 & $20 \cdot 6$ & 78 & 1606 & 68 & 1400 \\
\hline & \pm 667 & $\pm 45^{\circ}$ & $21 \cdot 2$ & $7^{6}$ & $161 \mathrm{I}$ & $66 \cdot 5$ & \\
\hline Orange & $\pm 63^{\circ} \mathrm{I}$ & $\pm 47^{2}$ & $2 \mathrm{I} \cdot 7$ & 75 & 1627 & $64 \div 5$ & I 399 \\
\hline & \pm 612 & \pm 494 & 22.2 & 73 & $1620^{\circ}$ & 64 & 1420 \\
\hline Yellow & $\pm 5^{8} 9$ & \pm 509 & 22.5 & 72 & 1620 & 63 & 1417 \\
\hline & $\pm 5^{8} 5$ & \pm 512 & $22 \cdot 6$ & $7^{2}$ & 1627 & 63 & 1423 \\
\hline Green & \pm 540 & $\pm 55^{6}$ & $23^{\cdot 6}$ & 69 & 1628 & 60 & $1+16$ \\
\hline & $\pm 5^{2} 3$ & \pm 574 & $23^{\circ} 9$ & $67 \cdot 5$ & 1603 & 59 & 1410 \\
\hline Blue & \pm 496 & \pm 607 & 24.6 & 65 & 1599 & 57 & 1402 \\
\hline & & \pm 638 & $25^{\circ} 2$ & 63 & 1587 & 55 & 1386 \\
\hline Indigo & \pm 464 & \pm 648 & 25.4 & 62 & I 574 & 55 & I 397 \\
\hline & \pm 437 & \pm 686 & $26 \cdot 3$ & 60 & 1578 & 54 & I 393 \\
\hline Violet & \pm 414 & $\pm 73^{8}$ & $27 \cdot I$ & $5^{6}$ & I517 & $5 \mathrm{I}$ & 1382 \\
\hline$"$ & $\pm 39^{8}$ & \pm 753 & $27 \cdot 4$ & 55 & 1507 & 50 & I 370 \\
\hline
\end{tabular}

Since the time of response of Pilobolus to the light of the tungsten and Nernst lamps, respectively, is by no means in direct proportion to their spectral energy values, and since there is found to exist some relation of the energy to the time of response, the question arises as to the possibility of expressing this relation in simple mathematical terms.

Wiesner (1879) has shown that the excitation of the plant increases less rapidly than the photic stimulus which produces it.

Pfeffer ( 1883 ), through the study of the reaction of swarm spores and bacteria to chemical stimuli, established the application of the WeberFechner law to plants. This law states that whereas the intensity of the stimulus increases in geometrical progression, the intensity of the reaction increases in arithmetical progression, or that response varies with the logarithm of the stimulus. This is expressed in the formula :

$$
S_{1}-S_{2}=A \log \frac{I_{1}}{I_{2}} \text {, where } S_{1} \text { and } S_{2} \text { are the sensations, } I_{1} \text { and } I_{2} \text { the }
$$
respective intensities of the stimuli, and $A$ is a constant which varies with the quality of the stimulus. 
This law, which was developed from a psycho-physical basis by Weber and Fechner (I882), was later shown by Müller (I878) to have a physiological significance. While Pfeffer showed its application to chemotropic stimuli, he expressed a belief that it would be found true in other forms of reaction, such as phototropism and geotropism.

Massart (I888) has shown that the irritability of the sporangiophores of Phycomycetes between two unequal intensities of light follow the WeberFechner law in their reaction.

If for the term 'sensation', which belongs to the realm of psychology, we substitute 'irritability' (cf. Preyer, 1874), the Weber-Fechner law may be tested in its application to the present problem within the limits of the measured intensities of the spectral regions of the two light sources. In Table IX are given the measured values of the energy and the presentation time, together with the solution of the formula to obtain the value of constant $A$ for each given region. The value of $A$, however, is seen to decrease rather uniformly through the spectral regions, and this strengthens the belief already expressed, namely that the two factors, wave-frequency and energy combined, give the phototropic response. If the value of $A$ in each case is multiplied by the square root of the wave-frequency of the region in which the measurements were made, an approximation to a general constant for the whole visible spectral region is obtained as shown in the last column of Table IX.

A comparison of the present series of results with those conforming to the Talbot law, as found by Nathansohn and Pringsheim (1907), Blaauw (I909), and others, shows a considerable difference. If quality of light is an essential, as shown by the present experiments, Pringsheim's methods in the light of these results are not quite fair, since the smoked glass used to reduce the quantity of light would interfere with its quality. This would cut down the different wave-lengths unequally and the heliotropic efficiency accordingly would be indefinite.

Patten working with blow-fly larvae in their relation to different intensities of light found in one series of experiments an excellent agreement with the Weber-Fechner law. A second series of measurements, however, gave different results. He concludes that the conformity with Weber's law, where it does occur, is entirely accidental. The results of the present series of experiments as shown in Table IX do not corroborate Patten's conclusion. Blackman (I905) has shown that a slight change in temperature causes a corresponding change throughout the physiological system of the organism. It is not strange, then, considering the difficulties in obtaining identical experimental conditions, that curves of response should vary considerably. The valuable mass of evidence presented by such investigators as Pfeffer (I883), Massart (I888), and others must lead to the belief that some fundamental factor exists in the protoplasm which gives rise to results conforming to the Weber-Fechner law. 


$$
\text { Parr.-The Response of Pilobolus to Light. }
$$

Tröndle (I9IO) in his effort to bring the results of his work concerning the relation of permeability to light intensity into conformity with the Talbot law has developed a formula deserving attention. His data show that the product of the reaction time less a constant $(k)$ multiplied by the intensity is always the same, expressed mathematically thus:

$$
I_{1}\left(t_{1}-k\right)=I_{2}\left(t_{2}-k\right) \text {. }
$$

The present series of data tested by this formula is given in Table $\mathrm{X}$, where $I_{n}$ and $I_{t}=$ intensity for a given wave-length, $t_{n}$ and $t_{T}=$ presentation times for 'second positive' reaction in the same wave-length from the Nernst and the tungsten lamps respectively. Here, too, there is seen to be a gradual decrease in the constant $k$ from red to violet. Again, multiplying the variable constant in each case by the square root of the frequency, a very fair constant result is obtained, as shown in the last column.

TABLE IX.

Wave- Fre-

length. quency

$\begin{array}{ccc}\begin{array}{c}\text { Wave- } \\ \text { length. }\end{array} & \begin{array}{c}\text { Fre- } \\ \text { quency. }\end{array} & I_{n} \\ 708 & 424 & 1.616 \\ 667 & 450 & 1.097 \\ 631 & 472 & 0.647 \\ 612 & 494 & 0.344 \\ 589 & 509 & 0.305 \\ 585 & 512 & 0.295 \\ 540 & 556 & 0.149 \\ 523 & 574 & 0.128 \\ 496 & 607 & 0.097 \\ 470 & 638 & 0.077 \\ 464 & 648 & 0.063 \\ 437 & 686 & 0.056 \\ 414 & 738 & * 0.038 \\ 398 & 753 & 0.032\end{array}$

Wave- Fre-

length. quency.

$\begin{array}{llllll}708 & 424 & 20.6 & 1.616 & 7.980 & 78 \\ 667 & 450 & 21 \cdot 2 & 1.097 & 5.760 & 76 \\ 631 & 472 & 21 \cdot 7 & 0.647 & 5.843 & 75 \\ 612 & 494 & 22.2 & 0.344 & 3.109 & 73 \\ 589 & 509 & 22.5 & 0.305 & 2.480 & 72 \\ 585 & 522 & 22.6 & 0.295 & 2.360 & 72 \\ 540 & 556 & 23.6 & 0.149 & 1.350 & 69 \\ 523 & 574 & 23.9 & 0.128 & 1 \cdot 050 & 67 \\ 496 & 607 & 24.6 & 0.097 & 0.735 & 65 \\ 470 & 638 & 25.2 & 0.077 & 0.686 & 63 \\ 464 & 648 & 25.4 & 0.063 & 0.578 & 62 \\ 437 & 686 & 26.3 & 0.056 & 0.364 & 60 \\ 414 & 738 & 27.1 & 0.038 & 0.145 & 56 \\ 398 & 753 & 27.4 & 0.032 & 0.130 & 55\end{array}$

\begin{tabular}{ll}
$I_{t}$ & \multicolumn{1}{c}{$S_{n}$} \\
$7 \cdot 990$ & 78 \\
$5 \cdot 760$ & 76 \\
5.843 & 75 \\
$3 \cdot 109$ & 73 \\
$2 \cdot 480$ & 72 \\
$2 \cdot 360$ & 72 \\
$1 \cdot 350$ & 69 \\
$1 \cdot 050$ & $67 \cdot 5$ \\
0.735 & 65 \\
0.686 & 63 \\
0.578 & 62 \\
0.364 & 60 \\
0.145 & 56 \\
0.130 & 55
\end{tabular}

Energy in ergs Presentation per sec.per cm. ${ }^{2}$ time in min.

$\begin{array}{llll}S_{t} & \log _{10} I_{n} & \log _{10} I_{t} & \log _{10} \frac{I_{n}}{I_{t}} \\ 68 & 0.2084 & 0.9020 & 0.6936 \\ 66.5 & 0.0302 & 0.7604 & 0.7302 \\ 64^{\circ} 5 & \overline{1} \cdot 8109 & 0.7666 & 0.9557 \\ 64 & \overline{1} \cdot 5366 & 0.4926 & 0.9560 \\ 63 & \overline{1} \cdot 4843 & 0.3945 & 0.9102 \\ 63 & \overline{1} \cdot 4698 & 0.3729 & 0.9031 \\ 60 & \overline{1} \cdot 1732 & 0.1303 & 0.9571 \\ 59 & \overline{1} \cdot 1072 & 0.0212 & 0.9140 \\ 57 & \overline{2} \cdot 9868 & \overline{1} \cdot 8629 & 0.8761 \\ 55 & \overline{2} \cdot 8865 & \overline{1} \cdot 8363 & 0.9498 \\ 55 & \overline{2} \cdot 7993 & \overline{1} \cdot 7622 & 0.9629 \\ 54 & \overline{2} \cdot 7482 & \overline{1} \cdot 5611 & 0.8129 \\ 51 & \overline{2} \cdot 5797 & \overline{1} \cdot 1613 & 0.5816 \\ 50 & \overline{2} \cdot 5052 & \overline{1} \cdot 1139 & 0.6087\end{array}$

$$
S_{1}-S_{2}=A \log \frac{\Gamma_{1}}{I_{2}}
$$

* This value is high according to Coblentz.

TABLE X.

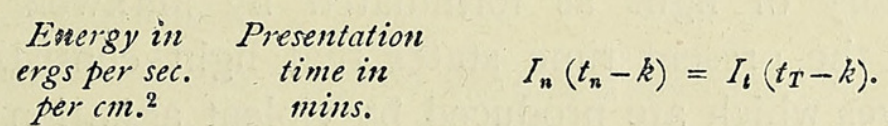
per cm. ${ }^{2}$ mins. 


\section{CONCLUSIONS AND THEORETICAL DISCUSSION.}

In considering the lack of conformity in the results of the investigations in the field of phototropism, it must be remembered that the plant is an organism existing in a physiological state continuously changing with the varied physical and chemical factors of its environment. A slight change in some one of the factors may markedly change the relation of the organism to every other factor (cf. Verworn, I9I3). Attention has already been called to the disturbing influence of the slightest trace of illuminating gas in the laboratory air upon Pilobolus. The researches of Crocker and Knight (I908) have shown its vitiating influence upon the higher plants. A review of many articles upon phototropism shows that illuminating gas has furnished the source of light for the experimental work. Thus Wiesner (1879), Figdor (1893), Pringsheim (I909), in order to subject the plant to different intensities of light varied the distance from the gas-flame from a few centimetres to several metres. Even though the presence of the gas in the room was not destructive to the plants used by these investigators, one might see from the work of Richter (1906), and Crocker and Knight (I908), the inhibiting effect that mere traces of the gas, or the products of combustion, have upon the sensitivity. The presence of these deleterious agents unquestionably affects in degrees, according to the distance of removal from the burner, the physiological condition of the plants and thereby effect a change in their irritability. The above objections naturally do not affect those experiments of Wiesner, Figdor, and Blaauw, where the sun or arc lights were used.

A noticeable difference between the results of the present series of experiments and those of earlier workers lies in the absence of the maximal and minimal points of response in the spectrum. Inquiry into the cause for this difference naturally leads first to the study of the nature of the light obtained from different sources.

The theory of light as formulated by Maxwell and accepted by physicists of the present time states that light consists of short electromagnetic waves which are produced by violent agitation of particles either from the electric current or other source of heat. Every source of light used for illumination has its own characteristic spectrum which differs from that of every other source, and the energy of radiation of each wave-length derived from one source differs from that of the corresponding wave-length from every other source (Nutting, pp. 12 and 197; Fery, 1908; Coblentz, 19II). Moreover, the spectrum from any given source changes according as the absolute temperature of the source is increased. The maximal spectral energy is found to move towards the violet end with a rise in the absolute temperature (Ives, I910; Drysdale, 1908; Nichols, 1903; Wien, 1893). Thus we find that bodies heated to $500^{\circ} \mathrm{C}$. emit only red rays in the visible spectrum, 
while the sun, at a probable temperature of $6,000^{\circ} \mathrm{C}$., emits the greatest amount of energy in the violet (cf. Duff, p. 455).

The Nernst and the tungsten lamps, heated to about $2,300^{\circ} \mathrm{C}$. (Hyde), show the spectral energy to increase from the ultra-violet to a maximum in the infra-red (Moll, I907; Coblentz, I9II). Since we find the energy highest in the red of the visible spectrum, we should expect from the discussion already given that in the response of Pilobolus, the slowness of the waves in the red region is in a measure compensated by their greater energy. The frequency having a much more noticeable effect than the energy values of the waves in the response of Pilobolus (Table IX, Figs. 3 and 4) may more than compensate for the lack of energy in the violet region. The regions between the red and violet having a gradual decrease in energy and an increase in frequency produce a response intermediate in time between that of the red and the violet. From the physical basis one could then predict the first maximum in ultra-violet and a second maximum in the orange in the response of plants exposed to a light having its maximum spectral energy in the orange, as the energy of this region would more than compensate for the slowness of the waves and a second maximum thus appear.

The results obtained by Guillemin ( 1857 ), who by the use of different prisms was able to obtain spectra from the sun in which the relative intensity varied for the same wave-length, substantiate this view. With a rock-salt prism, which transmits dark heat rays, he obtained the first maximum in the ultra-violet and a second maximum in the ultra-red; with a quartz prism, which transmits the chemical rays, he obtained the first maximum in the violet and a second between the red and infra-red; with a flint-glass prism, which best transmits the intermediate rays, he obtained the first maximum in the violet and a second in the green. He further found that the second maximum advanced more and more into the visible spectrum as the water vapour in the air was increased and the position of the sun approached the horizon.

Wiesner's results with seedlings in the sun's spectrum may in a measure be correlated with this line of thought. Due to the vapour, \&c., present in the atmosphere, the maximum energy of the sun's spectrum at noon is usually near the yellow (Langley, 1883, p. 33). The use of a biconvex lens would so focus these rays as to bring the intensity in the yellow to a very high value which may be responsible for the indifferent, or even negative heliotropic response (Oltmanns, I 892; Pringsheim, I 907; Blaauw, I909; Clark, I9I3). His results show a very regular decrease in the presentation time from the green into the ultra-violet, and bring the maximum irritability into the ultra-violet region. This would naturally follow from the increasing frequency and very considerable energy of this region; in the same manner as determined and recorded in this paper (Table IX). 
In Blaauw's experiments ( 1909 ), because of the higher absolute temperatures of the light sources (sun and arc-lamp), the maximum energy is near the yellow. He obtained no response in the red end beyond the yelloworange. In the indigo with a higher frequency and lower energy value he found a maximum response. This again accords beautifully with the results already described in this paper.

Divergent views held by previous investigators regarding the region of maximum response in the spectrum can be readily explained on the basis of energy value and frequency. That this has not previously been done is largely to be attributed to the difficulty encountered in determining the spectral values. Thus, Gardner (1844) observed that the intensity of light had only a subordinate influence. Sachs (1867) and Loeb (1906) state that the shorter waves are the more active and that the reaction is proportional to the intensity. Towle (I900) says of Cypredopsis that the response is shorter in the stronger light, 'though the difference is too slight to warrant one in drawing any inferences from it'. Allen and Jolivette (I9I3, p. 58 I) concluded from their experiments where coloured glass screens were used that 'the light of short wave-length has no preponderating influence at least in determining the phototropic reactions of Pilobolus'. It is noted in the experiment upon which this conclusion is based that the blue rays are balanced against the sum total of all the rays included in white light. From the relatively greater influence which the preceding pages of this paper have shown the frequency of light to exert upon Pilobolus, as compared to that of intensity, this conclusion from unmeasured quantities of light could be anticipated.

In a later paper, however, Miss Jolivette (I914, p. II9), using different kinds of light sources, states, 'Pilobolus fires its sporangia in larger numbers towards the lights in which the blue rays are greatest. In other words, it is more responsive to actinic rays. The intensities in the different wavelengths are not measurable.' She further says that the energy given off by the source of light apparently does not compare in effect with the distribution of the same in different portions of the spectrum. In the experiments using a I6-candle-power tungsten and a 32-candle-power carbon filament lamp the large majority of the sporangia went to the tungsten light, although its total energy was but half that of the carbon. From this she concludes that the differences in distribution in the spectrum outweigh in effect the differences in the total energy of the two sources, a qualitative conclusion which the present paper through quantitative methods has shown to be valid.

The writer will not endeavour to explain the physiological significance of either the Fechner or the Tröndle formula in relation to the reaction of Pilobolus to different quantities of light energy. That there is a physiological principle within the living protoplasm expressed in these formulae 
is beyond doubt. Furthermore, the present experiments show conclusively the existence of a definite relation of frequency to this change in the living protoplasm which produces response.

That the square root of the frequencies appears as a function of the reaction as calculated in the present paper is a striking fact in view of Nernst's results on the relation of frequency to response in electrical stimulation, where he found the response to vary inversely to the square root of the frequency (cf. Nernst, I 899; Verworn, I 91 3). Present observation would indicate that the light stimulus follows directly in the line of electrical stimulation.

The writer desires to make further investigation into the relations of response in these two fields of research.

\section{SUMMARY.}

I. Pilobolus responds to the light of all the regions of the visible spectrum.

2. The presentation time decreases gradually from red to violet. There is no indication of intermediate maxima or minima.

3. The presentation time does not vary in direct ratio with the measured value of the energy of the light in the different regions of the spectrum.

4. The presentation time varies in inverse ratio to the square roots of the wave frequency.

5. The product of the square root of the frequency times the presentation time, decreases with the decrease in the energy value of the spectral regions, and is an approximate constant for a given lightsource.

6. The spectral energy in its relation to the presentation time may be expressed approximately in the Weber-Fechner formula, if the wavefrequencies be made a function of the constant.

7. The relation of the spectral energy to the presentation time may also be approximately expressed in the Tröndle formula, the wave. frequencies being made a function of the constant.

The writer wishes to express her appreciation and gratitude to Professor Charles F. Hottes for inspiration and encouragement during the development of this problem, which was undertaken at his suggestion. She also wishes to thank Professor Jacob Kunz and Mr. Karrer, of the Physics Department, for their interest and assistance in the control of the delicate instruments used in the measurements of light.

UNIVERSITY OF ILLINOIS, 1916. 


\section{BIBLIOGRAPHY.}

Allen, R. F., and Jolivette, H. D. V.: A Study of the Light Reactions of Pilobolus. Trans.

Wis. Acad. Sci., vol. xvii, Pt. I, I9I4.

Ångstrom, K.: Das mechanische Äquivalent der Lichteinheit. Physik. Zeitschr., vol. v, I904.

BlaAuw, A. H.: Die Perzeption des Lichtes. I909.

BlaCKMAN : Optima and Limiting Factors. Ann. of Bot., 1905.

CLARK, O. L.: Úber negativen Phototropismus bei Avena sativa. Zeitschr. für Bot., Bd. v, I9I3.

CoblentZ, W. W. : Investigations of Infra-red Spectra. Pt. I, I905.

: Instruments and Methods used in Radiometry, vol. iv, No. 3, 1907.

: Selective Radiation from Solids. B. S. Bull., vol. vii, No. 2, 19 II.

Coemans, M. E. : Notice sur le Pilobolus crystallinus. 1859.

Crocker and KnIGHT: Effect of Illuminating Gas and Ethylene on Flowering Carnations. Bot. Gaz., vol. xlvi, 1908 .

Dandeno, J. B. : Phototropism under Light-rays of Different Wave-lengths. Science, vol. xviii, 1903.

DAY, E. C.: The Effect of Coloured Light on Pigment Migration in the Eye of the Crayfish. Bull. Mus. Comp. Zool., vol. liii, I9I I.

Drysdale, C. V.: Luminous Efficiency and the Mechanical Equivalent of Light. Proc. Roy. Soc., vol. $1 \times x x, 1907$.

Duff : A Text-book of Physics. J 908.

Engelman : Quant. Bezieh. zur Absorp. des Lichtes und Assimilation. Bot.Zeit., vol, xlii, I884.

FECHNeR: Psychophysik, vol.i, i,882.

FERY : Société de Physique. Bull. des Séances, p. I 48, 1908.

Figdor, W. : Versuche uiber die heliotropische Empfindlichkeit der Pflanzen. Sitzungsber. K. Akad. Wiss. Wien, vol. cii, Bd. i, I 893 .

Fischer v. Waldheim, A.: Ueber den Heliotropismus niederer Pilze. Citation from Batalin, Just's Botanischer Jahresbericht, vol. iii, I875.

Fröschel, PAUL: Über ein allgemeines reizphysiologisches Gesetz. Naturw. Wochenschrift, Bd. viii, 1909 .

: Untersuchungen über die heliotropische Präsentationszeit. Sitzungsber. K. Ak. Wiss. Wien, Math.-Nat. Klasse, Pt. I, I908.

GARDNER: Quotation from Wiesners Denkschrift. 1879.

GränTZ, Fritz: Ueber den Einfluss des Lichtes auf die Entwicklung einiger Pilze. I 898.

Gross, A. A.: The Reactions of Arthropods to Monochromatic Lights of Equal Intensities. Jour. Expt. Zool., vol. xiv, I913.

Guillemin: Ann. des Sc. Nat., Bot., $4^{e}$ série, vol. vii, 1857.

Haberlandt, G. F. J.: Die Sinnesorgane der Pflanzen. 1904.

HyDE: Quotation from Ives. I9IO.

IVES: Luminous Efficiency. Illum. Eng. Soc. Trans., igro.

JENniNGs, H. S. : Behaviour of the Lower Organisms. 1906.

Jolivette, H. D. V.: Studies on the Reactions of Pilobolus to Light Stimuli. Bot. Gaz., vol. Ivii, I9I.

Jost : Lectures on Plant Physiology. 1907.

KLeIN, J. : Zur Kenntniss des Pilobolus. Jahrb. für wiss. Bot,, vol. viii, 1872 .

LAKON, G. B.: Die Bedingungen der Fruchtkörperbildung bei Coprinus. Ann. Myc., vol. vii, No. 2,1907 .

Langley, S. P.: Researches on Solar Heat and its Absorption by the Earth's Atmosphere. Profess. Papers Sig. Service, vol. xvi, 1884 .

LaUrens, H.: The Reactions of Amphibians to Monochromatic Lights of Equal Intensities. Bull. Mus. Comp. Zool., vol. liii, I911.

MASSART, J.: Recherches sur les organismes inférieurs. Bull. Acad., Belg., sér. 3, t. xvi, 1888.

Moll, W. G. H. : Dissertation. Utrecht, 1907.

Müller, N. J. C. : Botan. Untersuchungen, Bd. i, 80,1872 .

: Grundlegung der Psychophysik. 1878 . 


\section{Parr.-The Response of Pilobolus to Light.}

Nathansohn und Pringsheim: Über die Summation intermittierender Lichtreize. Jahrb. f. wissensch. Bot., Bd. xlv, 1907.

Nernst, N.: Zur Theorie der elektrischen Reizung. Nachrichten der Königl. Gesellsch. d. Wissensch. zu Göttingen, Math.-Physik. Klasse, 1899.

Nichols, E. L. : On the Distribution of Energy in the Visible Spectrum. Physical Review, vol. xxi, 1905.

NutTing, P. G.: Outlines of Applied Optics. I9I 2.

Oltmanns : Positive and Negative Heliotropism. Flora, vol. lxxxiii, i897,

Patten, B. M. : An Analysis of certain Photic Reactions with reference to the Weber-Fechner Law. Am. Journ. of Physiol., vol. xxxviii, p. $3^{\mathbf{I}} 3$.

PAYer: Comptes rendus, vol. $x v, 1842$.

Pfeffer: The Physiology of Plants. Engl. transl. by Ewart. 1906.

Pringsheim : Reizbewegungen der Pflanzen. I9I2.

: Beiträge zur Biologie der Pflanzen, vol. ix, I909.

RADL, E.: Quotation from Mast, Light and the Behaviour of Organisms. I9IO.

Richter, O.: Ueber den Einfluss verunreinigter Luft auf Heliotropismus und Geotropismus. Sitzungsber. Kaiserl. Akad. Wiss. Wien, vol. exv, 1906.

SACHS, J. : Wirkungen farbigen Lichtes auf Pflanzen. Bot. Zeitung, vol. xvii, 1864.

Strasburger, E. : Wirkung des Lichtes und der Wärme auf Schwärmsporen. 1878.

Tröndle, A.: Der Einfluss des Lichtes auf die Permeabilität der Plasmahaut. Jahrb. f. wissensch. Bot., Bd. xlviii, 1910.

VERWORN, MAX : Irritability. I9I3.

: Allgemeine Physiologie, 1895.

Wager, H.: The Perception of Light in Plants. Ann. of Bot., vol. xxiii, 1909.

Wien, W.: Eine neue Beziehung der Strahlung schwarzer Körper zum zweiten Hauptsatz der Wärmetheorie. Sitzungsberichte d. Akad. d. Wissensch. Berlin, Pt. I, 1893.

- Wiesner, J.: Die heliot. Erscheinungen im Pflanzenreiche. Denkschriften d. K. K. Akad. Wien, vol. $x x x i x, 1879$.

YeRKes, R. M. : Reactions of Daphnia. An. Jour. Physiol., vol. iv, I900.

ZaNTEDESCHI : De l'influence qu'exercent sur la végétation des plantes et la germination des graines les rayons solaires transmis à travers des verres colorés. Comptes rendus, vol. xvi, 1843 .

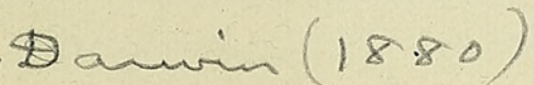




\section{$2 \mathrm{BHL}$ Biodiversity Heritage Library}

Parr, Rosalie Mary. 1918. "The response of Pilobolus to light." Annals of botany 32, 177-205. https://doi.org/10.1093/oxfordjournals.aob.a089670.

View This Item Online: https://www.biodiversitylibrary.org/item/238284

DOI: https://doi.org/10.1093/oxfordjournals.aob.a089670

Permalink: https://www.biodiversitylibrary.org/partpdf/320213

\section{Holding Institution}

Smithsonian Libraries

\section{Sponsored by}

Biodiversity Heritage Library

\section{Copyright \& Reuse}

Copyright Status: Not in copyright. The BHL knows of no copyright restrictions on this item.

This document was created from content at the Biodiversity Heritage Library, the world's largest open access digital library for biodiversity literature and archives. Visit BHL at https://www.biodiversitylibrary.org. 